\title{
Dispersal and migration of a specialist waterbird: where do Eurasian Spoonbills (Platalea leucorodia) come to Hungary from?
}

\author{
Csaba PignicZKI
}

Received: March 06, 2017 -Accepted: June 15, 2017

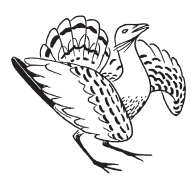

Pigniczki, Cs. 2017. Dispersal and migration of a specialist waterbird: where do Eurasian Spoonbills (Platalea leucorodia) come to Hungary from? - Ornis Hungarica 25(1): 1-24. DOI: 10.1515/orhu-2017-0001 Abstract Between 1950 and 2016, 254 individuals of Eurasian Spoonbill (Platalea leucorodia) of foreign origin were observed during their dispersal or migration in Hungary from eight countries. Colour-ringed birds originating from Serbia, Croatia and the Czech Republic were the most commonly observed, while individuals from Italy, the Danube Delta (Romania) and the Wadden Sea area (Denmark and The Netherlands) were observed rarely in Hungary. Only metal ringed Spoonbills were recovered from Austria. All age-classes were found in Hungary: juveniles were the most common, while 2cy immatures formed the rarest class. Adults from the Wadden Sea area, and also from the Danube Delta were observed in Hungary during the breeding season, implying potential gene flow between those areas and the Carpathian Basin. My results predict that the breeding population of the Carpathian Basin forms a unique subunit of a metapopulation which is in close contact with the Czech population. The nesting of adults of Serbian and Croatian origin was confirmed in Hungary. Two prospecting subadults (4cy) were observed in Hungarian colonies, one was from Serbia, and the other was from Italy. One adult (5cy) occurred in several Hungarian wetlands in a short period before breeding, which probably explored habitats for breeding or for feeding. Spoonbills of Czech, Serbian, Croatian and Italian origin observed in Hungary used the Central Mediterranean or the Adriatic Flyway. Individuals from the East Atlantic population arrived to Hungary by shifting their migration routes. One bird from the Danube Delta wintered in Tunisia, where it probably joined Hungarian breeders and reached Hungary with them. Adults and juveniles from the Czech Republic used the wetlands around Lake Neusiedler as a stop-over and staging area during autumn migration. My results suggest that Hungarian wetlands play an important role in the movements and breeding of Spoonbills in Central Europe, thus, the management and conservation of these wetlands are essential for the future.

Keywords: Carpathian Basin, colour rings, metal rings, gene flow, metapopulation, flyway shift

Összefoglalás Magyarországon 1950 és 2016 között 254 külföldön jelölt kanalasgémet (Platalea leucorodia) észleltek, melyek nyolc országból származtak. A legtöbb megfigyelés a Cseh Köztársaságban, Szerbiában és Horvátországban színes gyürüvel jelölt egyedekröl érkezett, míg néhányat Olaszországban, Romániában a Duna-deltában, illetve Dániában és Hollandiában, a Watt-tenger környékén jelöltek. Ausztriából csak fémgyürüs madarak kerültek meg Magyarországon. Az észlelt madarak különbözö korcsoportokba tartoztak, de a leggyakoribbak a fiatalok (1cy), míg a legritkábbak a második naptári évesek voltak. Fészkelési időben olyan öreg kanalasgémeket is megfigyeltek a Kárpát-medencében, amelyek a Watt-tengertől (Dánia és Hollandia) vagy a Duna-deltából (Románia) származtak, ami a lehetséges génáramlásra utal. A Kárpát-medencén belül fészkelő populáció valószínüleg egy metapopulációs alegységet alkot, és úgy tünik, hogy a Cseh-medence állománya is szorosan kapcsolódik hozzá. Hazai gémtelepeken valószínüleg felderítő mozgást végző két subadult (4cy) egyedet figyeltek meg, az egyik Szerbiából, a másik Olaszországból származott. Egy öreg (5cy) kanalasgém a fészkelési időszak előtt Magyarország több vizes élőhelyén is felbukkant rövid időn belül, lehetséges, hogy a potenciális fészkelövagy táplálkozóhelyeket járta végig a költés előtt. A csehországi, szerbiai, horvát- és olaszországi eredetủ madarak a Közép-Mediterrán vagy az Adriai Madárvonulási Útvonalat használták. A kelet-atlanti populációból néhány egyed úgy jutott el Magyarországra, hogy megváltoztatta a korábban használt vonulási útvonalát. Egy Duna-deltából származó kanalasgém feltehetően úgy jutott el hazánkba, hogy Tunéziában telelt, ahol valószínúleg csatlakozott a Magyarországra költeni visszatérő fajtársai közé. A Cseh Köztársaságból származó öreg és fiatal mada- 
rak a Fertő-tó környékét használták megállóhelyként az öszi vonulásuk alatt. Eredményeim azt mutatják, hogy a magyarországi vizes élőhelyek fontos szerepet játszanak a kanalasgémek kóborlásában és költésében Közép-Európában, így ezeknek a vizes élőhelyeknek a védelme és megfelelő kezelése különösen fontos a jövőre nézve is.

Kulcsszavak: Kárpát-medence, színes gyürük, fémgyürűk, génáramlás, metapopuláció, vonulási út váltása

Kiskunság National Park Directorate, 6000 Kecskemét, Liszt Ferenc utca 19., Hungary,

e-mail: csaba.spoonbill@gmail.com

\section{Introduction}

The Eurasian Spoonbill is a specialist waterbird of key conservation importance as it is also considered as a flagship, umbrella and indicator species (Pigniczki \& Végvári 2015). Therefore, several authors studied them in detail, including their dispersal, migration, survival, habitat use, ecology and conservation (Triplet et al. 2008, Navedo et al. 2010, Lok et al. 2011, 2013a, 2013b, Kralj et al. 2012, Overdijk \& Navedo 2012, Pigniczki \& Végvári 2015, Pigniczki et al. 2016, Sullender et al. 2016, Pigniczki 2017). Spoonbills breeding in Europe are typically divided into at least two large, distinct breeding populations, with one population in Atlantic and the other in Central and South-East Europe (Triplet et al. 2008). These populations have different breeding areas, migration routes, and wintering areas (Brouwer 1964, De le Court \& Aguilera 1997, Smart et al. 2007, Triplet et al. 2008, Pigniczki 2010, Lok et al. 2011, Pigniczki \& Karcza 2013, Pigniczki \& Végvári 2015, Pigniczki et al. 2016), and early studies found no overlap between those two distinct populations (Brouwer 1964, Müller 1984). Because Spoonbills from the Czech Republic, the Carpathian Basin and Italy migrate along the Adriatic Flyway or the Central Mediterranean Flyway (Kralj et al. 2013, Pigniczki et al. 2016), it seems straightforward to treat them as a distinct Central European population and to separate them from the East European breeders that nest in the Danube Delta, eastern Greece and other parts of East Europe (Kralj et al. 2012, Pigniczki et al. 2016, 2017).

The largest Central European Spoonbill population breeds in Hungary (Triplet et al. 2008, Pigniczki 2010, Pigniczki \& Karcza 2013, Pigniczki \& Végvári 2015). This population fluctuated between 600 and 1400 pairs in the last decade, depending on the particular years (Pigniczki \& Végvári 2015). Spoonbills marked in foreign countries were reported to occur in Hungary during the breeding period (Pigniczki 2010). Hungarian wetlands play a paramount role for Spoonbills during post-breeding and post-fledging dispersal and during the beginning of autumn migration, as large numbers of individuals, belonging to all age classes, are found in proper areas. The maximum number of Spoonbills in a suitable site can be as high as 1700 individuals by the end of summer, estimated in wetlands of Hortobágy (Pigniczki 2010) and in a soda pan of Pusztaszer (Pigniczki 2016). Colour-ringed birds from Serbia and Croatia were also regularly observed in those flocks during late summer (Pigniczki 2009, 2010, Kralj et al. 2012, Pigniczki \& Karcza 2013). Spoonbills were also observed in Hungary during spring migration, and occasionally immatures, subadults and non-breeding adults spend the summer here (Kralj et al. 2012, Pigniczki \& Végvári 2015, Pigniczki et al. 2016).

The aim of the study was to understand the breeding population dynamics, dispersal and migration patterns of Spoonbills in Hungary and in Central Europe by focusing on birds 
marked abroad and observed in Hungary. Spoonbills marked abroad and observed in Hungary were studied previously only marginally (Pigniczki 2009, 2010, Pigniczki \& Karcza 2013). Here I summarize the Hungarian recoveries and resights of Spoonbills ringed abroad and describe their breeding, migration and dispersal behaviour.

\section{Materials and methods}

I used the recovery and resight records of Spoonbills that were ringed outside Hungary and found or observed in Hungary at least once until the end of 2016.

Several colour ringing programs have been running across Europe (Denmark, Germany, Belgium, the Netherlands, France, Spain, Italy, the Czech Republic, Croatia, Serbia, Romania, Bulgaria and Greece) to mark Spoonbills (Overdijk 2008, Pigniczki 2010, www.cr-birding.org, www.crb-photoguide.com), while mainly metal rings were used in Slovakia and Austria (Müller 1984, Cepak 2008, Pigniczki 2010). Further details on colour ringing schemes and the observation network are given in Pigniczki and Végvári (2015) and Pigniczki et al. (2016).

The resighting records used in this study came from observations from several field ornithologists, nature photographers and from my personal observations. In addition to personal observations and reading of colour rings, I used automatic cameras (Reconyx HC500) during the post-fledging dispersal at the roosting and feeding sites to collect data on colourringed individuals in 2014 and 2015. Automatic cameras were also installed in some colonies during ringing actions to study the behaviour of Spoonbills and to collect data on colour-ringed non-juveniles in 2015 and 2016.

To characterise the age of individuals, I used the calendar year age category for each record as follows: a bird is one year old (1cy) in the year of hatching until 31 December of that year; two years old (2cy) in the year after the year of hatching, and so on. I defined five different age-groups: one-year-old Spoonbills (1cy or juveniles); two-year-old individuals (2cy or immatures); three-year-old birds (3cy or immatures); four-year-old birds (4cy or sub-adults) and finally, birds older than four years (4+ or adults). Previous studies supposed that sub-adult (4cy) Spoonbills probably do not breed or they nest only in low proportions in the Carpathian Basin (Pigniczki 2010, Pigniczki \& Végvári 2015).

Spoonbills start breeding in the first half of March, while some individuals of late arrivals finish breeding in August. Most of the yearlings fledge by mid-June, indicating that most of the adult Spoonbills breed before that period. Breeding lasts for 11-12 weeks between pair forming and fledging of juveniles from the colony (Pigniczki 2015). Thus, the core of breeding season falls in May and June (Pigniczki \& Végvári 2015). Although April is also important for breeding, a few adult Spoonbills still arrive to the breeding grounds in late April. Therefore, I treated observations of adult birds between 15 April and 30 June as indicators of breeding. To estimate the probability of breeding for colour-ringed Spoonbills, I used three categories: 1) confirmed breeding, 2) probable breeding and 3) possible breeding. Breeding probability was analysed in all Hungarian colonies and in the Austrian colony at Lake Neusiedler, which is very close to the Hungarian border, and usually the breeders of that colony are observed in Hungary during their foraging trips. 
I treated breeding as confirmed in a colony if a colour-ringed bird (1) was seen in the colony at least once and nesting activity was observed during that observation, or (2) fed at least one juvenile in the colony or shortly after the fledglings left the colony, or (3) fed a colour-ringed fledged juvenile from a known natal colony. This method was warranted because adult Spoonbills feed only their own chicks, and usually attack alien chicks begging for food (Cs. Pigniczki pers. obs.).

I treated breeding as probable breeding, if a bird was seen at least twice in or in the vicinity of a breeding colony and if at least one of those observations was made between 15 April and 30 June, and if the other observation between 1 March and 30 June was at least ten days apart from the observation in the core of breeding period.

I used the possible breeding category if (1) an adult was seen twice in the vicinity of a particular colony and one of those observations was made between 15 April and 30 June, but the two observations were made less than ten days apart, or (2) an adult was seen only once in the vicinity of a colony between 15 April and 30 June, or (3) an adult was seen in the vicinity of a colony in which breeding was late, or if it was seen together with freshly fledged juveniles from that colony, but feeding of fledglings was not observed.

In a few cases when an adult bird could be assigned to more than one colonies with breeding probability, I chose the colony closest to the natal colony of the observed individual and used the distance-records between that colony and the natal area in the statistical analyses. If a bird moved more than $100 \mathrm{~km}$ in May and June, or if it used the same area for a long period in the breeding season, I assumed that that individual skipped nesting or failed to breed. These cases were excluded from the breeding analyses.

A dispersal event during breeding was defined as the movement of an adult individual between its natal area and the colony where the probability of its breeding was highest. When breeding probability was equal for two or more colonies, I used the colony closer to the natal area to avoid overestimating dispersal distances. Dispersal was classified as short-distance if the dispersal distance not more than $100 \mathrm{~km}(\leq 100 \mathrm{~km})$, and as long-distance if this distance was more than $100 \mathrm{~km}(100 \mathrm{~km}<)$ (De le Court \& Aguilera 1997, Pigniczki \& Végvári 2015). I used the data on Hungarian observations of Spoonbills that hatched in the following regions: 1) Vojvodina in Serbia, along River Tisa, 2) the area between Rivers Sava and Drava in Croatia, 3) fishponds in the Czech Basin, 4) the lowlands of River Po in Italy, 5) Danube Delta in Romania, and 6) the Wadden Sea area, which includes birds from The Netherlands, Denmark, Germany and Belgium. I compared the number of birds resighted from different regions using Pearson's chi-square test to test the differences in the number of colour-ringed Spoonbills recorded in Hungary and the number of colour-ringed individuals that have never been detected in Hungary for each region.

Generally, I used the shortest distances between the natal colonies and observation sites in Hungary. However, I used the maximum distances between the natal colony and the observation location in Hungary in case of 1 cy individuals, during the post-natal dispersal.

I compared the first observation and the last observation date of Spoonbill individuals with foreign origin in Hungary in case of juveniles. Julian dates were used during these analyses. Records of birds out of four regions were compared using Kruskal-Wallis H-test, including birds that originated from Serbia, Croatia, the Czech Republic and Italy. 
Only those records were used, where there was no doubt about the credibility of the observations. New circumstances made me to overwrite some old published records: for example, all the records of some individuals were deleted from the Hungarian database, because photos or new information proved that ring-reading mistakes happened. Thus, I deleted all the records of two juvenile individuals, one of which hatched in the Danube Delta and the other in Becej, and also all the records of a Greek individual, because the reports from Hungary were the results of misreadings (Pigniczki \& Karcza 2006, Pigniczki 2010).

To calculate distances between the natal site and the observation area, analyses were carried out in the $\mathrm{R}$ statistical programming environment ( $\mathrm{R}$ Development Core Team 2016), including the "fossil" package for calculating geographic distances (Vavrek 2011). For statistical analyses the PAST program was used (Hammer et al. 2001).

\section{Results}

The complete database contains 926 observation records of 254 individuals ringed abroad, and observed in Hungary between 1950 and 2016 (Table 1). In total, 240 colour-ringed spoonbills marked abroad as chicks were resighted in Hungary. Furthermore, one adult individual marked in Italy with unknown natal area was also observed in Hungary. Eleven Spoonbills recovered and one was resighted in Hungary marked abroad only with metal ring. Interestingly, an Italian immature individual observed at Kis-Balaton, Hungary, which was identified as a hybrid of Eurasian Spoonbill $\times$ African Spoonbill (Platalea leucorodia $\times$ Platalea alba).

Spoonbills moved to Hungary from eight countries (Table 1, Figure 1). Most of them hatched in the Carpathian Basin (Serbia, Croatia and Austria), some had Czech or Italian origin, and only a few arrived from the Danube Delta (Romania) or from the Wadden Sea area (Denmark, The Netherlands).

Table 1. The proportion of Spoonbills observed in Hungary by the region of their origin, and the number of metal-ringed and colour-ringed individuals by the country of their origin. Signs: * - ringed as adult; ** - hybrid of Eurasian Spoonbill $\times$ African Spoonbill

1. táblázat A Magyarországon megfigyelt kanalasgémek százalékos aránya regionális eredetük szerint, illetve az egyes országokból származó, Magyarországon megfigyelt fémgyűrűs és színes gyűrűs madarak száma. A táblázatban használt jelölések: * - öreg madárként gyűrǔzve; ** - kanalasgém $\times$ afrikai kanalasgém hibrid

\begin{tabular}{|l|c|l|c|c|c|}
\hline \multicolumn{1}{|c|}{ Region } & $\%$ & \multicolumn{1}{c|}{ Country } & Metal ringed & Colour-ringed & Total \\
\hline \multirow{3}{*}{ Carpathian Basin } & \multirow{3}{*}{$84.3 \%$} & Austria & 10 & 0 & 10 \\
\cline { 3 - 6 } & & Serbia & 1 & 134 & 135 \\
\cline { 3 - 6 } & Croatia & 0 & 69 & 69 \\
\hline Czech Basin & $7.1 \%$ & Czech Republic & 1 & 17 & 18 \\
\hline Po River Basin & $6.7 \%$ & Italy & 0 & $\left(15+1^{*}\right)+1^{* *}$ & 17 \\
\hline Danube Delta & $0.4 \%$ & Romania & 0 & 1 & 1 \\
\hline \multirow{2}{*}{ Wadden Sea area } & \multirow{2}{*}{$1.6 \%$} & The Netherlands & 0 & 3 & 3 \\
\cline { 3 - 6 } & & Denmark & 0 & 1 & 1 \\
\hline
\end{tabular}




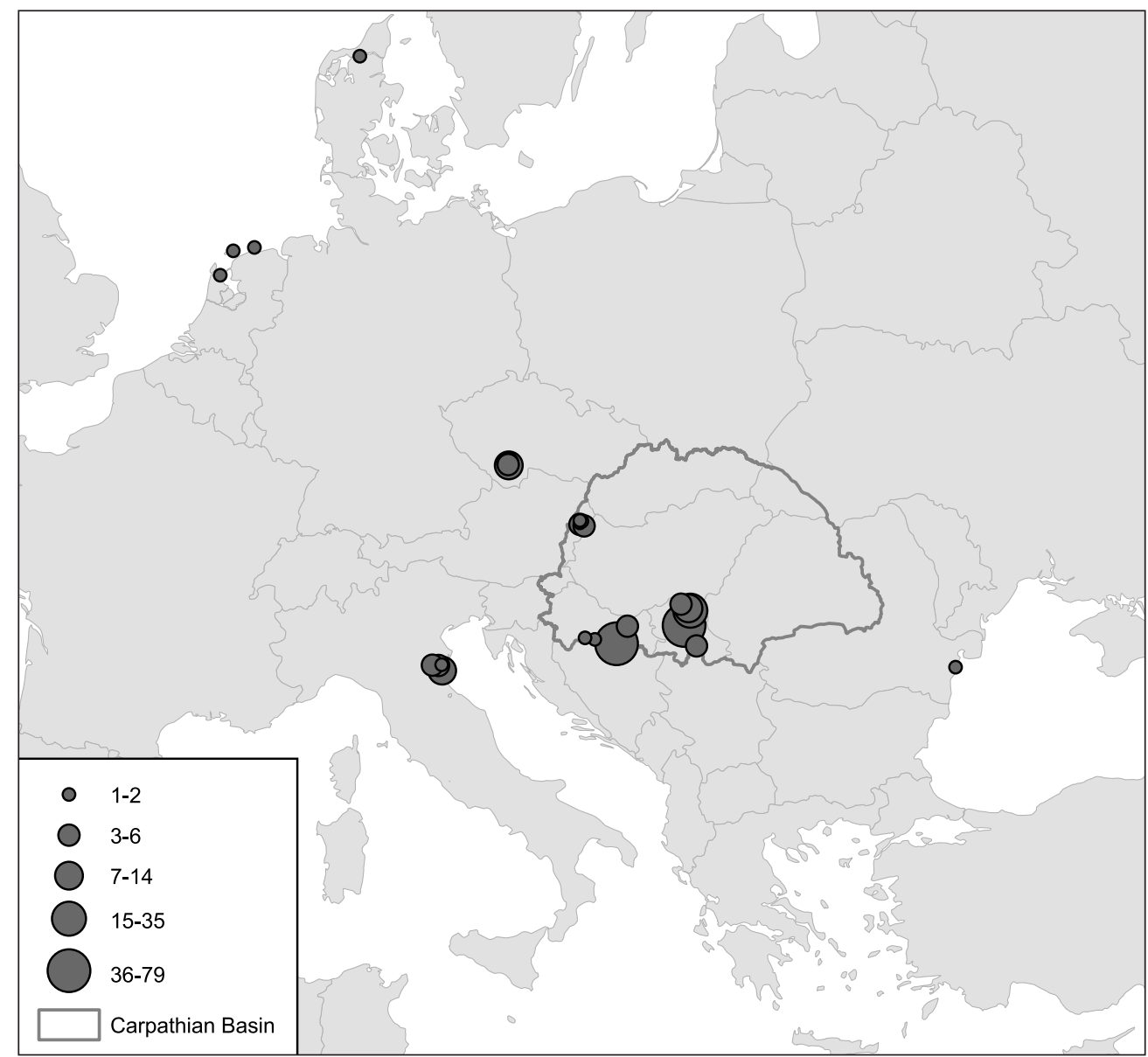

Figure 1. Natal area of Eurasian Spoonbills that were observed later in Hungary. The size of circles indicates the number of Spoonbills observed in Hungary

1.ábra A kanalasgém fiókák származási helye, melyek később megfigyelésre kerültek Magyarországon. A körök mérete jelzi, hogy egy-egy telepről hány kanalasgém jutott el Magyarországra

The largest proportion of Spoonbills visiting Hungary consisted of birds from the Czech Republic and Serbia, while the smallest proportion was from the Wadden Sea area (Table 2). The number of birds observed vs. not observed in Hungary (Table 2) differed significantly among the six regions (Pearson's $\chi^{2}=2315.1, \mathrm{df}=5, \mathrm{p}<0.0001$ ).

The average distance between the natal colony and the nearest observation site in Hungary was $201.1 \pm 187.5 \mathrm{~km}$ (mean $\pm \mathrm{SD} ; \mathrm{n}=253$ ) (Table 3 ). Spoonbills could reach Hungary even from The Netherlands and Denmark, covering $1287 \mathrm{~km}$ and $1255 \mathrm{~km}$, respectively.

Most of the individuals of foreign origin observed in Hungary were juveniles, while the number of 2cy birds was the lowest (Figure 2). After age 2cy, the number of observed individuals grew gradually by age category and peaked in the adult age, although this peak was at little more than half the number of juveniles observed (Figure 2). 
Table 2. Number of Spoonbills colour-ringed as chicks in the different regions, and the number and proportion of these individuals observed in Hungary. D: Germany, NI: The Netherlands, Dk: Denmark, B: Belgium, Ro: Romania

2. táblázat Fióka korban színes gyűrűvel jelölt kanalasgémek száma régiónként, illetve a Magyarországon megfigyelt egyedek száma és százalékos aránya. D: Németország, NI: Hollandia, Dk: Dánia, B: Belgium, Ro: Románia

\begin{tabular}{|l|c|c|c|}
\hline & $\begin{array}{c}\text { Number of } \\
\text { colour-ringed pulli }\end{array}$ & $\begin{array}{c}\text { Number of colour-ringed } \\
\text { individuals observed in } \\
\text { Hungary }\end{array}$ & $\%$ \\
\hline Serbia & 685 & 134 & $19.56 \%$ \\
\hline Croatia & 781 & 69 & $8.83 \%$ \\
\hline Czech Republic & 54 & 17 & $31.48 \%$ \\
\hline Italy & 2419 & 16 & $0.66 \%$ \\
\hline Wadden Sea area (D, NI, Dk, B) & 11929 & 4 & $0.03 \%$ \\
\hline Danube Delta (Ro) & 219 & 1 & $0.46 \%$ \\
\hline
\end{tabular}

Table 3. The means of the minimum distances and their standard deviation between the natal area and the closest observation sites in Hungary for Spoonbills of foreign origin. The table also contains the maximum value of distance between natal area and observation sites in Hungary for each country

3. táblázat A kanalasgém-elmozdulások minimális távolságának átlaga és szórása a kikelési helyük és a hozzá legközelebb fekvő magyar megfigyelési vagy megtalálási pont között külföldön jelölt madarak esetén. A táblázat tartalmazza a kanalasgém-elmozdulások maximum értékét is a kelési hely és a magyarországi megfigyelési helyek között származási ország szerinti bontásban

\begin{tabular}{|l|r|r|r|}
\hline \multicolumn{1}{|c|}{ Country } & \multicolumn{1}{c|}{ N } & \multicolumn{1}{c|}{ Mean \pm SD } & Max. \\
\hline Serbia & 135 & $108.5 \pm 57.2 \mathrm{~km}$ & $341 \mathrm{~km}$ \\
\hline Croatia & 69 & $225.5 \pm 79.6 \mathrm{~km}$ & $421 \mathrm{~km}$ \\
\hline Austria & 10 & $106.2 \pm 82.5 \mathrm{~km}$ & $273 \mathrm{~km}$ \\
\hline Czech Rep. & 17 & $270.4 \pm 58.1 \mathrm{~km}$ & $400 \mathrm{~km}$ \\
\hline Italy & 16 & $588.2 \pm 78.9 \mathrm{~km}$ & $685 \mathrm{~km}$ \\
\hline Danube Delta & 1 & $668 \mathrm{~km}$ & $668 \mathrm{~km}$ \\
\hline Wadden Sea area & 4 & $1168.5 \pm 123.9 \mathrm{~km}$ & $1287 \mathrm{~km}$ \\
\hline All & 253 & $201.1 \pm 187.5 \mathrm{~km}$ & $1287 \mathrm{~km}$ \\
\hline
\end{tabular}

Flyways of Spoonbills marked abroad

Birds from Serbia (Figure 3) and Croatia (Figure 4) were observed in Hungary in high numbers during breeding time and during post-fledging dispersal. The observations of Serbian and Croatian birds fell between 28 February and 16 October in Hungary. These birds of Serbia and Croatia that were observed in Hungary moved along the Central Mediterranean/Adriatic Flyway to the central Mediterranean Basin, and a Croatian individual was found dead in the Algerian part of the Sahara (Table 4). Immatures from Croatia and Serbia also regularly visited Hungary. An adult (5cy) Spoonbill of Serbian origin was observed at several locations of Hungary during early spring before breeding (Figure 5). Several

adults from Croatia and Serbia were observed in Hungarian colonies during the breeding season.

Little is known on the birds hatched in Austria, because they were marked only with metal rings. The few data show that individuals were found in Hungary mainly during the post-natal dispersal, but also during breeding season (Figure 6). 


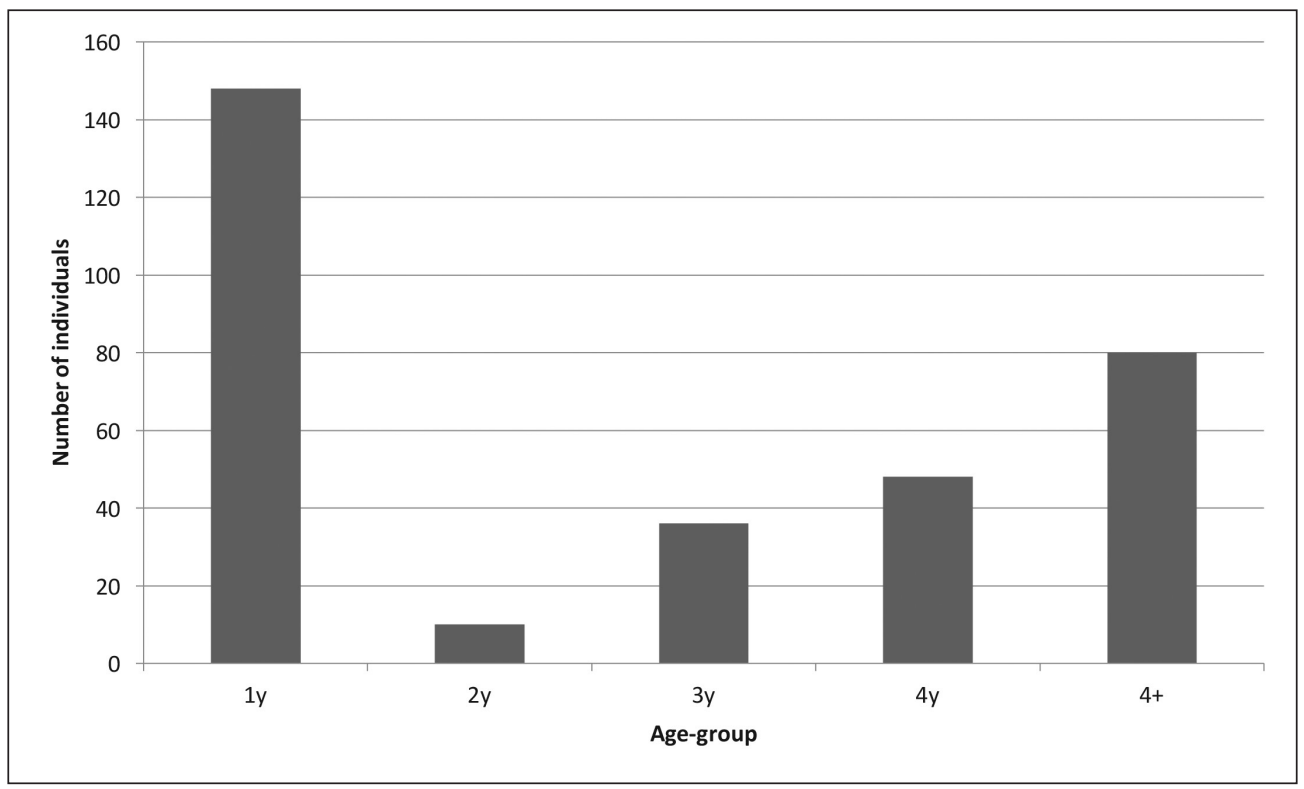

Figure 2. Age-structure of Spoonbills of foreign origin marked as chicks and observed in Hungary 2.ábra A Magyarországon megfigyelt, fióka korban külföldön jelölt kanalasgémek korcsoportstruktúrája

Table 4. Colour ringed Spoonbills of foreign origin observed in Hungary and their number in different countries. Table contains only those records that were marked while they were juveniles

4. táblázat A Magyarországon is megfigyelt külföldi színes gyűrűs kanalasgémek megfigyelési helyei országonkénti bontásban. Csak azok a madarak szerepelnek benne, melyeket fiókaként gyürüztek

\begin{tabular}{|c|c|c|c|c|c|c|c|c|}
\hline \multirow[b]{2}{*}{$\begin{array}{l}\text { Location of } \\
\text { observation }\end{array}$} & \multicolumn{7}{|c|}{ Origin of chicks } & \multirow[b]{2}{*}{ Total } \\
\hline & Serbia & Croatia & $\begin{array}{l}\text { Czech } \\
\text { Rep. }\end{array}$ & Italy & Denmark & $\begin{array}{l}\text { The } \\
\text { Netherlands }\end{array}$ & $\begin{array}{c}\text { Romania } \\
\text { (Danube } \\
\text { Delta) }\end{array}$ & \\
\hline Denmark & & & & & 1 & & & 1 \\
\hline Germany & & & & & 1 & 1 & & 2 \\
\hline The Netherlands & & & & & & 3 & & 3 \\
\hline France & & & & & & 1 & & 1 \\
\hline Poland & & & & & & 1 & & 1 \\
\hline Czech Republic & & & 12 & & & 1 & & 13 \\
\hline Austria & & & 3 & & & & & 3 \\
\hline Slovakia & & & 2 & & & & & 2 \\
\hline Romania & 1 & & & & & & & 1 \\
\hline Serbia & 23 & 1 & 1 & & & & & 25 \\
\hline Croatia & 10 & 7 & 1 & 1 & & 1 & & 20 \\
\hline Montenegro & 1 & & & & & & & 1 \\
\hline Greece & 1 & 1 & & & & & & 2 \\
\hline Italy & 12 & 11 & 3 & 9 & 1 & & & 36 \\
\hline Morocco & & & & 1 & & & & 1 \\
\hline Algeria & & 2 & & & & & & 2 \\
\hline Tunisia & 35 & 17 & 5 & 2 & & & 1 & 60 \\
\hline Libya & & 1 & & & & & & 1 \\
\hline Senegal & & & & & 1 & & & 1 \\
\hline
\end{tabular}




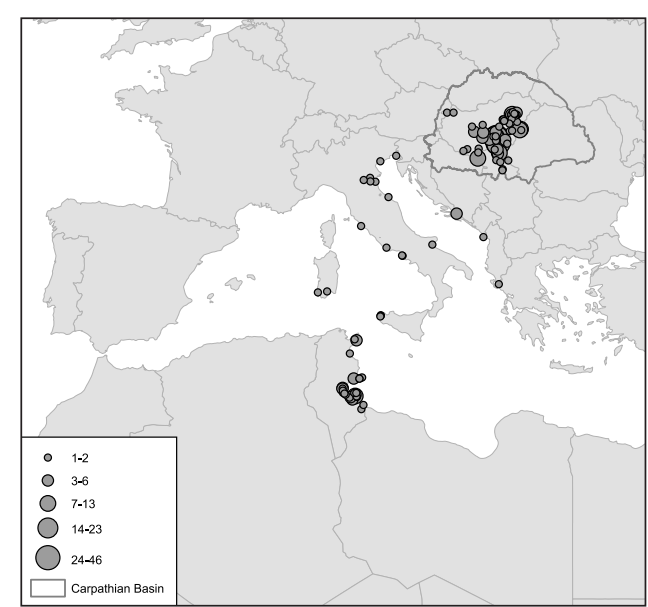

Figure 3. All observation sites of Spoonbills marked in Serbia and observed in Hungary. Spoonbills of Serbian origin observed in Hungary followed the Central Mediterranean or Adriatic Flyway during their migration. The size of circles indicates the number of individuals for all locations

3. ábra Szerbiában gyűrűzött, majd Magyarországon megfigyelt kanalasgémek öszszes megfigyelési helye. A Szerbiában gyűrüzött, majd Magyarországon is megfigyelt kanalasgémek vonulásuk során a Közép-Mediterrán vagy az Adriai Vonulási Útvonalat követték. A körök mérete jelzi az adott helyen megfigyelt egyedek számát

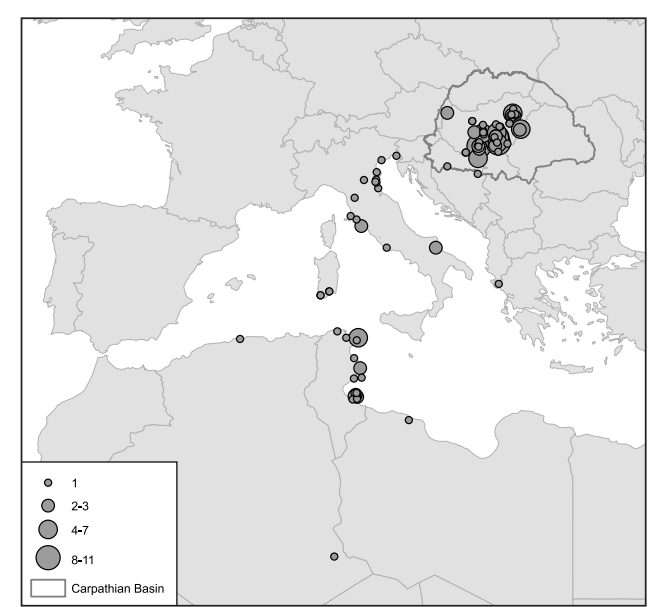

Figure 4. All observation sites of Spoonbills marked in Croatia and observed in Hungary. Spoonbills of Croatian origin observed in Hungary followed the Central Mediterranean or Adriatic Flyway during their migration. The size of circles indicates the number of individuals for all locations

4. ábra Horvátországban gyűrüzött, majd Magyarországon megfigyelt kanalasgémek összes megfigyelési helye. A Horvátországban gyürüzött, majd Magyarországon is megfigyelt kanalasgémek vonulásuk során a Közép-Mediterrán vagy az Adriai Vonulási Útvonalat követték. A körök mérete jelzi az adott helyen megfigyelt egyedek számát

Individuals from the Czech Republic made regular stops during their autumn migration in Transdanubia, mainly at Lake Neusiedler. Three individuals were observed at Lake Neusiedler during breeding season, some of them in more years. Birds from the Czech Republic that were observed in Hungary generally moved along the Central Mediterranean Flyway to Italy and Tunisia to winter there (Table 4, Figure 7).

Spoonbills from Italy visited Hungary during post-fledging dispersal, or while they were immatures (2cy and 3cy), sub-adults or young adults (5cy and 6cy). They moved along the Central Mediterranean or Adriatic Flyway to winter in North Africa, mainly in Tunisia (Table 4, Figure 8). An individual in its 5cy was observed in Hungary on 28 March 2007, but later it returned to Italy and was observed in the vicinity of River Po on 17 June 2007.

Single individuals were observed in Hungary from Denmark and Romania (Danube Delta) (Table 4, Figure 9) and three from the Netherlands (Table 4, Figure 10). Two of them appeared to use the Central Mediterranean/Adriatic Flyway. 


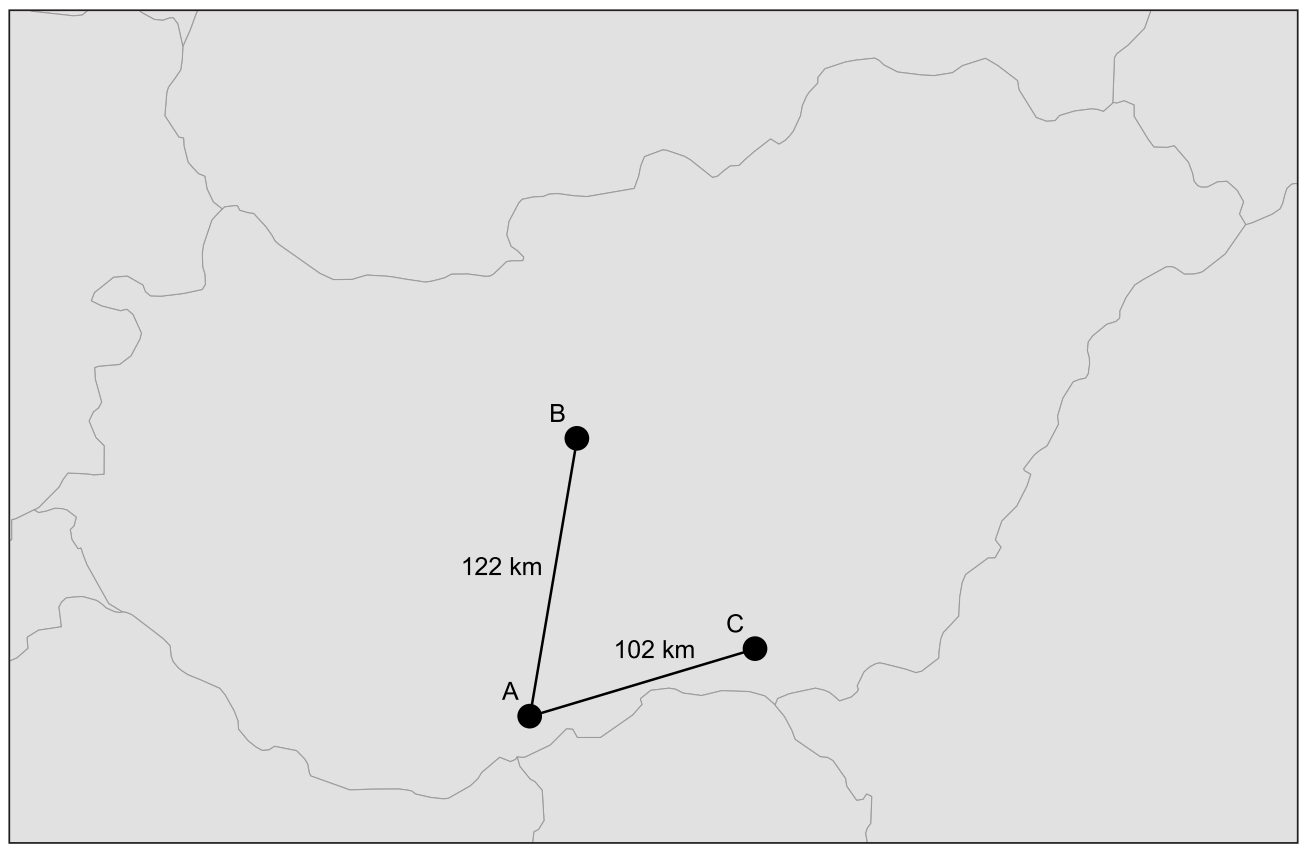

Figure 5. Movement of the W/W[5J] Spoonbill in Hungary before breeding season. That individual was observed at Nagybaracska ('A' location) on 13 March 2008, and it was seen $122 \mathrm{~km}$ away at Apaj ('B' location) on 17 March 2008. The individual moved back to Nagybaracska after eight days, and it was observed there between 25 and 28 March 2008. Eleven days later that individual was seen $102 \mathrm{~km}$ away at Szeged ('C' location) between 8 and 10 April 2008

5. ábra A W/W[5J] kódú kanalasgém mozgása Magyarországon a fészkelési időszak előtt. Ezt az egyedet 2008. március 13-án Nagybaracskán (A helyszín) figyelték meg, majd négy nap múlva 122 km-rel távolabb, Apajon (B helyszín) észlelték. Nyolc nap múlva visszament Nagybaracskára, ahol 2008. március 25-28. között tartózkodott. Tizenegy nap múlva 102 km-rel távolabb, Szegeden (C helyszín) került elö, ahol 2008. április 8-10. között figyelték meg

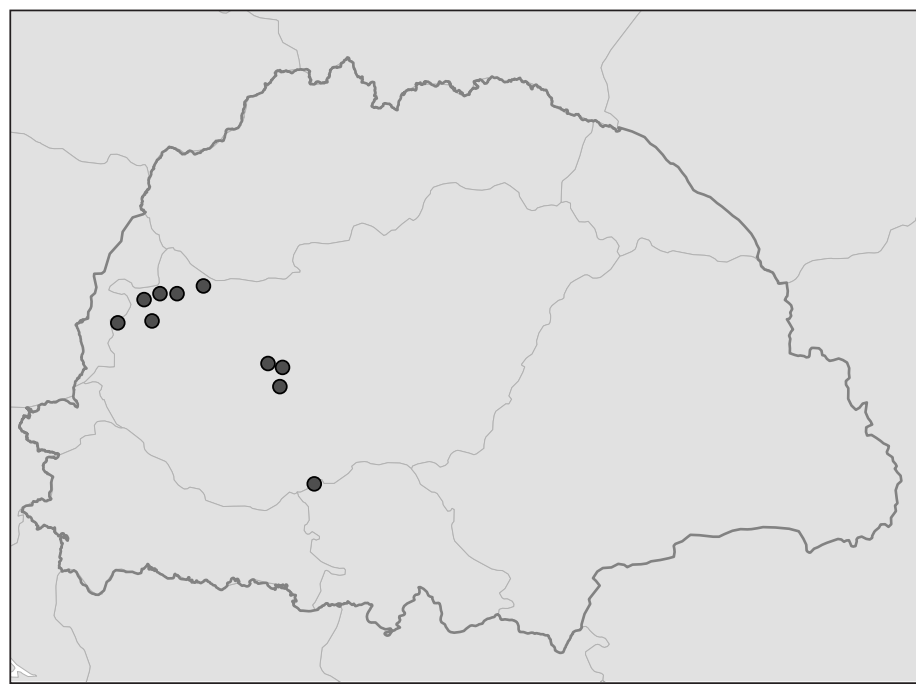

Figure 6. All recovery sites of Spoonbills marked in Austria and observed in Hungary

6. ábra Ausztriában gyürűzött, majd Magyarországon megkerült kanalasgémek összes megkerülési helye 


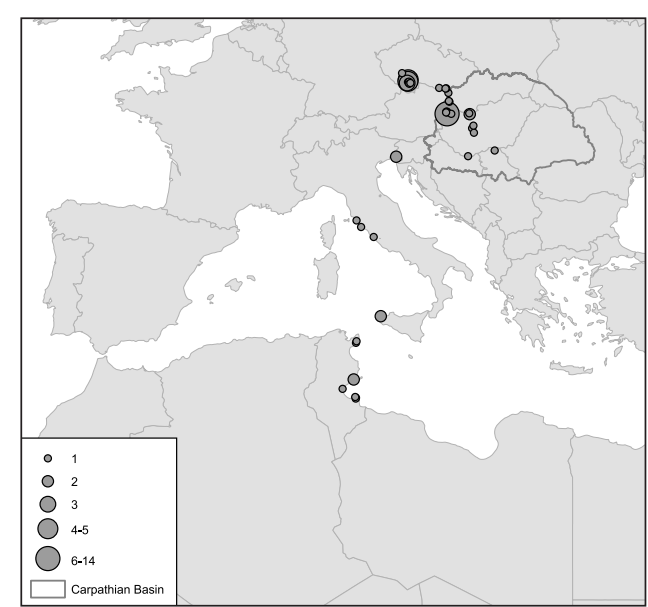

Figure 7. All observation sites of Spoonbills marked in the Czech Republic and observed in Hungary. Spoonbills of Czech origin observed in Hungary followed the Central Mediterranean Flyway during their migration. The size of circles indicates the number of individuals for all locations

7.ábra A Cseh Köztársaságban gyűrüzött, majd Magyarországon megfigyelt kanalasgémek összes megfigyelési helye. A Cseh Köztársaságban gyűrüzött, majd Magyarországon is megfigyelt kanalasgémek vonulásuk során a Közép-Mediterrán Vonulási Útvonalat követték. A körök mérete jelzi az adott helyen megfigyelt egyedek számát

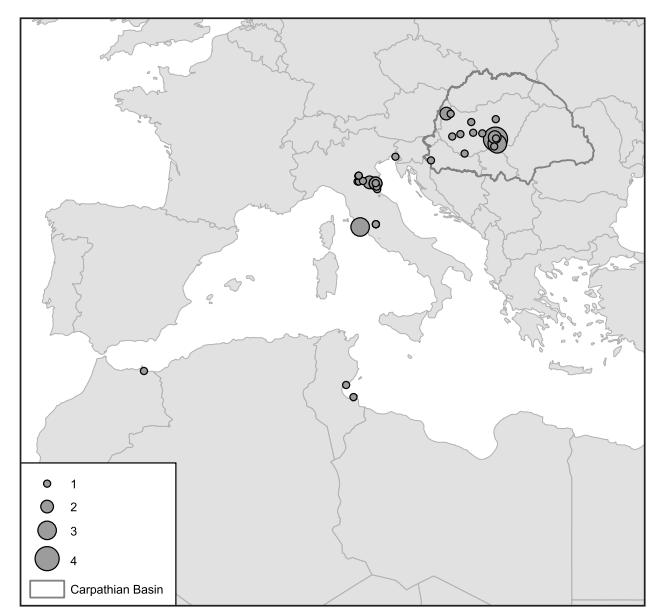

Figure 8. All observation sites of Spoonbills marked in Italy and observed in Hungary. Spoonbills of Italian origin observed in Hungary followed the Central Mediterranean Flyway during their migration. The size of circles indicates the number of individuals for all locations

8. ábra Olaszországban gyürűzött, majd Magyarországon megfigyelt kanalasgémek összes megfigyelési helye. Az Olaszországban gyűrűzött, majd Magyarországon is megfigyelt kanalasgémek vonulásuk során a Közép-Mediterrán Vonulási Útvonalat követték. A körök mérete jelzi az adott helyen megfigyelt egyedek számát

\section{Juvenile Spoonbills during post-fledging dispersal}

142 juvenile spoonbills were observed in Hungary. Twelve individuals visited Hungary from the Czech Republic, three from Italy, while 83 arrived from Serbia and 44 arrived from Croatia. Furthermore, 6 birds from Austria were recovered in Hungary.

Generally, birds from Italy reached Hungary first (204.7 \pm 34.0 julian days, $\mathrm{n}=3$ birds), followed by individuals from Serbia $(224.2 \pm 28.7, \mathrm{n}=83)$ and Croatia $(231.4 \pm 22.1, \mathrm{n}=44)$, and finally juveniles from the Czech Republic $(235.8 \pm 16.6, n=12)$. These arrival dates of juveniles did not differ significantly (Kruskal-Wallis $\mathrm{H}$-test, $\mathrm{H}=4.79$, $\mathrm{p}=0.188$ ).

Spoonbills from Italy left Hungary first $(219.3 \pm 10.1$ julian days, $n=3$ birds), followed by individuals from Serbia $(233.8 \pm 28.6, \mathrm{n}=83)$ and Croatia $(239.5 \pm 23.4, \mathrm{n}=44)$ and finally by birds from the Czech Republic $(241.1 \pm 19.8, \mathrm{n}=12)$. The median dates of last observations did not differ significantly $(\mathrm{H}=3.035, \mathrm{p}=0.386)$.

Juvenile spoonbills covered different distances to reach Hungary during their dispersal (or possible migration in case of individuals from the Czech Republic). Spoonbills covered 


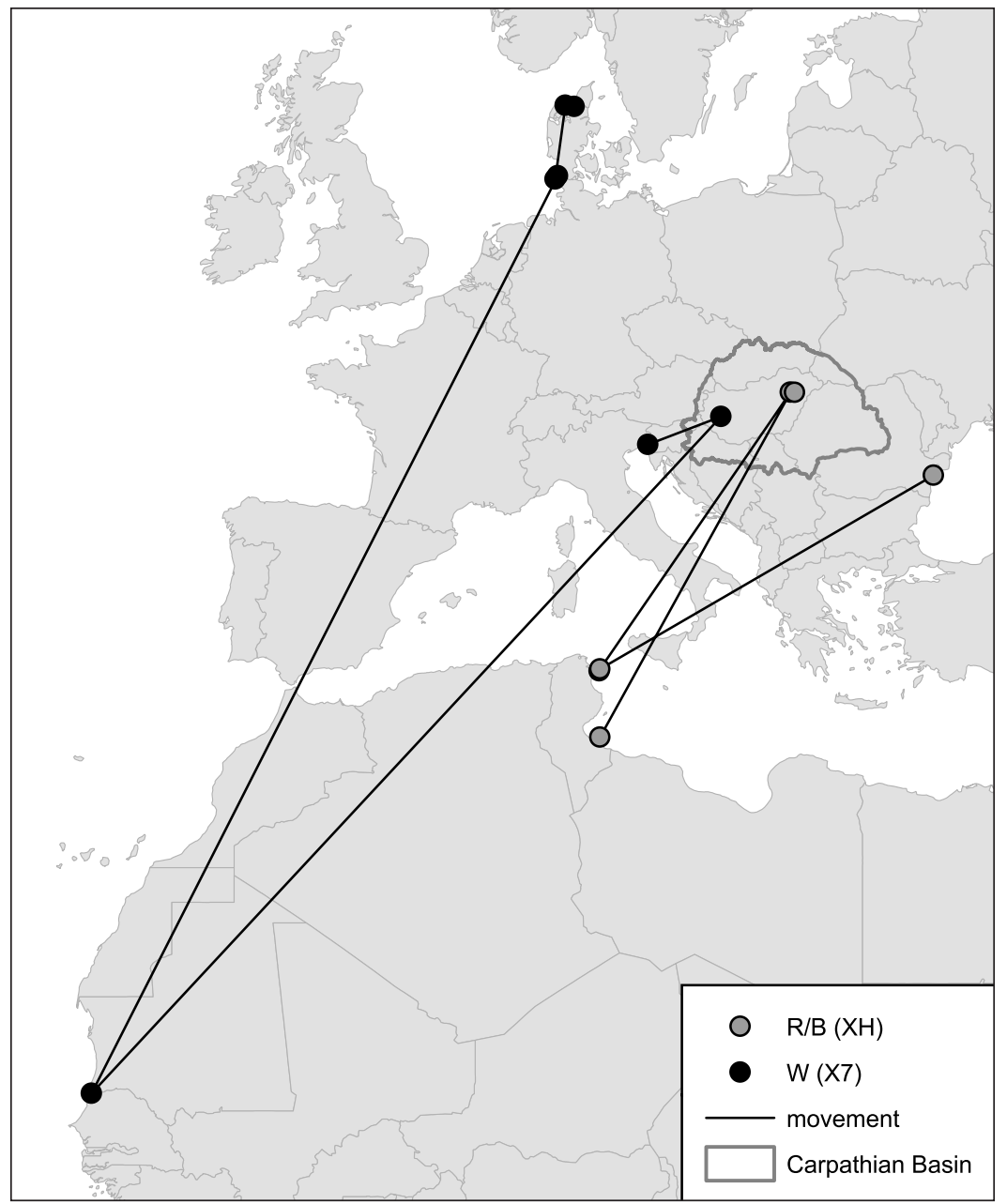

Figure 9. All observation sites of Spoonbills marked in Denmark or Romania and observed in Hungary. A bird from Denmark (W (X7)) marked in 2004 as a pullus used the East Atlantic Flyway, and migrated as far as Djoudj National Park, Senegal, it was observed there on 12 November 2006. That individual was photographed later at Lake Balaton (Hungary) on 16 July 2013, and at River Isonzo (Italy) on 12 March 2016. A bird (R/B (XH)) from the Danube Delta (Romania) was observed in its 3cy at Cape Bon, Tunisia, and later in its $5 c y$ at Hortobágy area, Hungary on 23 April and 8 September 2007. That individual wintered on the island of Djerba, Tunisia in the winter of 2011/2012

9. ábra Dániában és Romániában gyűrűzött, majd Magyarországon megfigyelt kanalasgémek öszszes megfigyelési helye. Egy Dániában 2004-ben fiókaként gyürűzött egyed (W (X7)) a Kelet-Atlanti Madárvonulási Útvonalat követve Szenegálba, a Djoudj Nemzeti Parkba vonult, ahol 2006. november 12-én megfigyelték. Később ugyanezt a madarat a Balaton mellett 2013. július 16-án, majd Olaszországban, az Isonzó-folyó mellett lefényképezték 2016. március 12-én. Egy madarat $(R / B(X H))$ a Duna-deltából 3. naptári éves korában Cape Bon félszigetén, Tunéziában észleltek, majd 5. naptári éves korában a Hortobágyon 2007. április 23án és szeptember 8-án figyeltek meg. Később ez a madár Tunéziában, Djerba szigetén telelt 2011/12 telén 


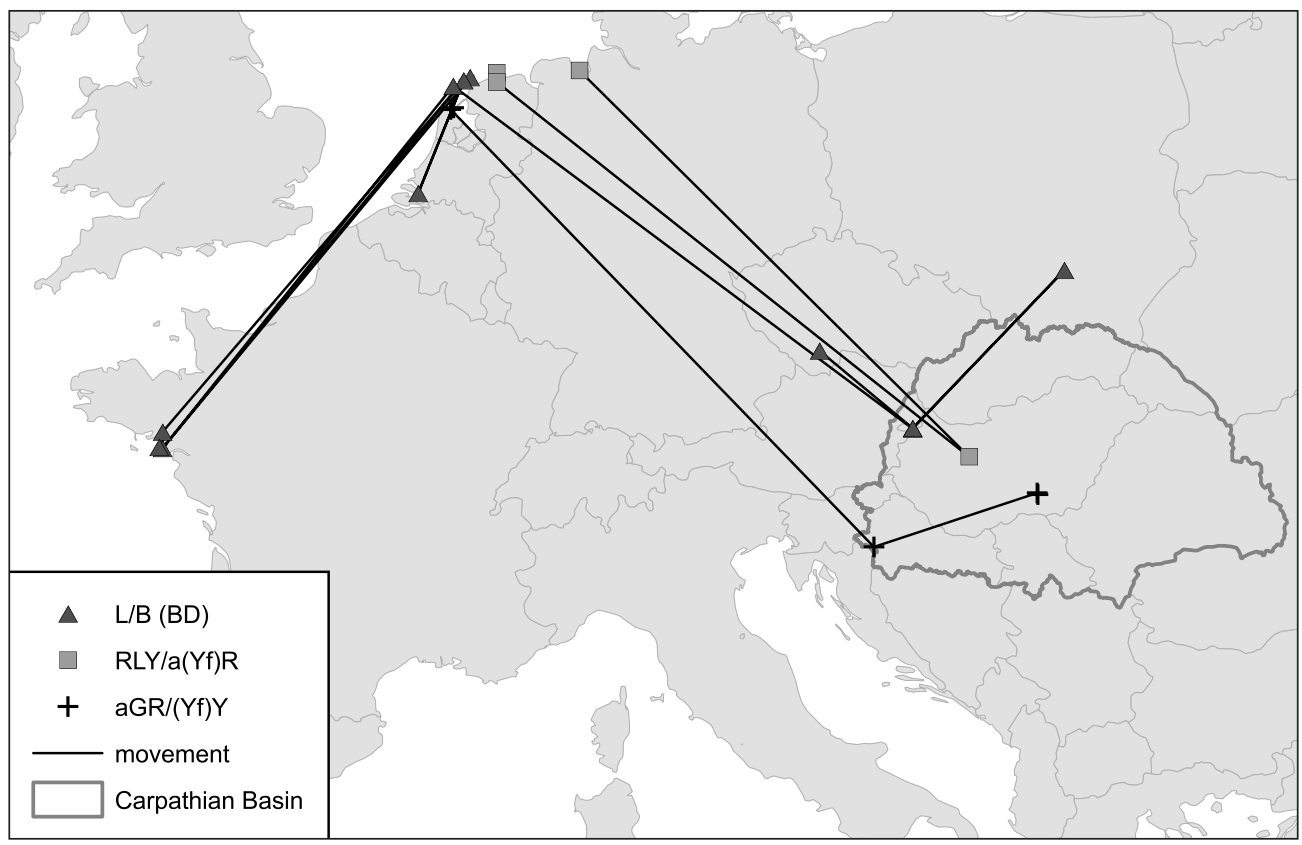

Figure 10. All observation sites of Spoonbills marked in The Netherlands and observed in Hungary. One 3cy immature individual (RLY/a(Yf)R) hatched in The Netherlands was seen in Hungary on 26 June 2011. Interestingly, 33 days later that individual was observed in the German coast of the Wadden Sea between 30 July and 22 August 2011. Another Dutch individual (L/B (BD)) was regularly seen on the Atlantic coast of France between 2005 and 2011 during winter, and regularly seen in the Dutch Wadden Sea area between 2007 and 2012 during breeding season and post-breeding dispersal. That individual was observed in the Hungarian part of Lake Neusiedler between 17 May and 15 August 2013 (13 observations). During the following spring migration it stopped at a fishpond in south Poland on 19 April, and was also seen later in the Hungarian part of Lake Neusiedler between 28 June and 4 September 2014. The last observation of that individual was made on a fishpond in the Czech Republic on 14 April 2015. The third Dutch individual (aGR/(Yf)Y) was 4cy old, it was observed in Croatia on 16 May, and later also in Hungary between 1 July and 19 August 2016

10. ábra Hollandiában gyűrűzött, majd Magyarországon megfigyelt kanalasgémek összes megfigyelési helye. Egy 3. naptári éves madár (RLY/a(Yf)R), mely Hollandiában kelt, 2011. június 26-án Magyarországon mutatkozott. Érdekes módon 33 nappal később ezt a madarat a Watt-tenger német részén olvasták le, és itt tartózkodott 2011. július 30. és augusztus 22. között. Egy másik hollandiai madár (L/B (BD)) 2005 és 2011 között rendszeresen megfigyelhető volt télen Franciaország atlanti partjánál, illetve fészkelési időben és a költést követő diszperzió alatt a holland Watt-tenger mellett került elő 2007 és 2012 között több alkalommal. Ez az egyed a Fertő magyar oldalán 13 alkalommal került szem elé 2013. május 17. és augusztus 15. között. A következő évben, tavaszi vonulásakor megállt egy halastavon Lengyelországban 2014. április 19-én, de később, június 28. és szeptember 4 között újra a Fertő mellett észlelték. Ezt a madarat utoljára 2015. április 14-én, a Cseh Köztársaságban látták egy halastavon. A harmadik hollandiai egyedet (aGR/(Yf)Y) 4. naptári évesen Horvátországban, 2016. május 16-án, majd Magyarországon észlelték július 1. és augusztus 19. között 
Table 5. Natal colony, natal year of Spoonbills with possible/probable and confirmed breeding sites in Hungary or the Austrian part of Lake Neusiedler, the year, probability and age of those breedings and the distance between the natal area and their breeding sites. A: possible breeding; B: probable breeding; C: confirmed breeding; *: probable skipped breeding; Cz: Czech Republic; Dk: Denmark; Hr: Croatia; NI:The Netherlands; Ro: Romania; RS: Serbia

5. táblázat Az egyes kanalasgémek kikelési helye és éve, a lehetséges/feltételezett/biztos fészkelés helye, ideje, valószínűsége és kora, illetve a kikelési hely és a fészkelési hely közötti távolsága. A: lehetséges fészkelés; B: valószínű fészkelés; C: biztos fészkelés; *: a költés kihagyásának gyanúja. Cz: Cseh Köztársaság; Dk: Dánia; Hr: Horvátország; Nl: Hollandia; Ro: Románia; RS: Szerbia

\begin{tabular}{|c|c|c|c|c|c|c|c|}
\hline Ring code & Natal colony & Natal year & Breeding colony or area & $\begin{array}{l}\text { Breeding } \\
\text { year }\end{array}$ & $\begin{array}{l}\text { Breeding } \\
\text { probability }\end{array}$ & \begin{tabular}{|c|} 
Age of \\
breeding
\end{tabular} & $\begin{array}{l}\text { Distance of natal and } \\
\text { breeding site (km) }\end{array}$ \\
\hline \multirow{2}{*}{ 0/B [TA] } & \multirow{2}{*}{ Krapje Dol (Hr) } & \multirow{2}{*}{2007} & \multirow{2}{*}{ Hortobágy Fishpond } & 2015 & $C$ & $9 y$ & 418 \\
\hline & & & & 2013 & $A$ & $7 y$ & 418 \\
\hline $\mathrm{B} / \mathrm{W}[\mathrm{LC}]$ & Becej (RS) & 2007 & Lake Kolon or Kis-rét & 2011 & $C$ & $6 y$ & $147-161$ \\
\hline$W[E / 0 T]$ & Coka (RS) & 2011 & Lake Csaj & 2016 & $B$ & $6 y$ & 74 \\
\hline \multirow{3}{*}{ W/W [UE] } & \multirow{3}{*}{ Mydlovary (CZ) } & \multirow{3}{*}{2003} & \multirow{3}{*}{ Lake Neusiedler (A) } & 2007 & B & $5 y$ & 223 \\
\hline & & & & 2008 & A & $6 y$ & 223 \\
\hline & & & & 2010 & $\mathrm{~A}$ & $8 y$ & 223 \\
\hline \multirow{3}{*}{$\mathrm{R} / \mathrm{B}[\mathrm{SP}]$} & \multirow{3}{*}{ Nasice (Hr) } & \multirow{3}{*}{2004} & Hortobágy Fishpond & 2012 & $B$ & $9 y$ & 321 \\
\hline & & & Lake Neusiedler (A) & 2009 & A & $6 y$ & 280 \\
\hline & & & $\begin{array}{l}\text { Polgár Fishpond or } \\
\text { Hortobágy Fishpond }\end{array}$ & 2016 & A & $13 y$ & $321-339$ \\
\hline \multirow{2}{*}{$\mathrm{R} / \mathrm{B}[\mathrm{TL}]$} & \multirow{2}{*}{ Slavonski Brod (Hr) } & \multirow{2}{*}{2003} & Lake Csaj or Szeged Fishpond & 2008 & B & $6 y$ & $221-236$ \\
\hline & & & Szeged Fishpond & 2009 & $A$ & $7 y$ & 221 \\
\hline $\mathrm{R} / \mathrm{B}[\mathrm{LA}]$ & Slavonski Brod (Hr) & 2003 & Szeged Fishpond & 2012 & $B$ & $10 y$ & 221 \\
\hline $\mathrm{R} / \mathrm{B}[\mathrm{EA}]$ & Slavonski Brod (Hr) & 2003 & Lake Csaj & 2007 & $B$ & $5 y$ & 236 \\
\hline O/B [YP] & Slavonski Brod (Hr) & 2003 & Fehér-szék. Fülöpszállás & 2011 & $B$ & $5 y$ & 213 \\
\hline W/W [2R] & Jazovo (RS) & 2006 & Szeged Fishpond & 2014 & $B$ & $9 y$ & 52 \\
\hline W/W [Y0] & Becej (RS) & 2003 & Lake Csaj & 2007 & $B$ & $5 y$ & 117 \\
\hline \multirow{2}{*}{ W/W [A9] } & \multirow{2}{*}{ Becej (RS) } & \multirow{2}{*}{2003} & Lake Csaj & 2007 & $B$ & $5 y$ & 117 \\
\hline & & & Biharugra Fishpond & 2008 & $\mathrm{~A}$ & $6 y$ & 201 \\
\hline \multirow{4}{*}{ W/W [7X] } & \multirow{4}{*}{ Becej (RS) } & \multirow{4}{*}{2003} & $\begin{array}{l}\text { Lake Kolon or Fehér-szék, } \\
\text { Fülöpszállás }\end{array}$ & 2011 & B & $8 y$ & $147-154$ \\
\hline & & & Lake Kolon & 2012 & $\mathrm{~B}$ & $9 y$ & 147 \\
\hline & & & Hortobágy area & 2013 & $\mathrm{~A}$ & $10 y$ & 245 \\
\hline & & & Lake Csaj or Lake Kolon & 2015 & $B$ & $12 y$ & $117-147$ \\
\hline \multirow{3}{*}{$\mathrm{B} / \mathrm{B}[6 \mathrm{~T}]$} & \multirow{3}{*}{ Jazovo (RS) } & \multirow{3}{*}{2007} & Szeged Fishpond & 2012 & $B^{*}$ & $6 y$ & $52 ?$ \\
\hline & & & Lake Csaj & 2014 & $\mathrm{~A}$ & $8 y$ & 81 \\
\hline & & & Szeged Fishpond & 2015 & $B$ & $9 y$ & 52 \\
\hline W [E/MT] & Becej (RS) & 2011 & Szeged Fishpond & 2016 & $B$ & $6 y$ & 89 \\
\hline \multirow{2}{*}{ L/B [BD] } & \multirow{2}{*}{ Terschelling (NI) } & \multirow{2}{*}{2005} & \multirow{2}{*}{ Lake Neusiedler (A) } & 2013 & $B$ & $9 y$ & 1006 \\
\hline & & & & 2014 & $\mathrm{~A}$ & $10 y$ & 1006 \\
\hline \multirow{4}{*}{ W/W [NA] } & & & & 2007 & $\mathrm{~A}$ & $5 y$ & 226 \\
\hline & Nálri (Cᄀ) & 2003 & 1 le Nouciod ro (A) & 2010 & $\mathrm{~A}$ & $8 y$ & 226 \\
\hline & NakrI (CZ) & 2003 & Lake Neusiedler (A) & 2011 & $\mathrm{~A}$ & $9 y$ & 226 \\
\hline & & & & 2012 & A & $10 y$ & 226 \\
\hline L/L [Y9] & Mydlovary (Cz) & 2003 & Lake Neusiedler (A) & 2013 & A & $11 y$ & 223 \\
\hline
\end{tabular}




\begin{tabular}{|c|c|c|c|c|c|c|c|}
\hline Ring code & Natal colony & Natal year & Breeding colony or area & $\begin{array}{c}\text { Breeding } \\
\text { year }\end{array}$ & $\begin{array}{l}\text { Breeding } \\
\text { probability }\end{array}$ & $\begin{array}{c}\text { Age of } \\
\text { breeding }\end{array}$ & $\begin{array}{l}\text { Distance of natal and } \\
\text { breeding site (km) }\end{array}$ \\
\hline \multirow{2}{*}{$\mathrm{R} / \mathrm{B}[\mathrm{DB}]$} & \multirow{2}{*}{ Nasice (Hr) } & \multirow{2}{*}{2003} & \multirow{2}{*}{ Lake Csaj } & 2007 & A & $5 y$ & 186 \\
\hline & & & & 2016 & A & $14 y$ & 186 \\
\hline $\mathrm{R} / \mathrm{B}[\mathrm{TH}]$ & Slavonski Brod (Hr) & 2003 & Szeged Fishpond & 2008 & A & $6 y$ & 221 \\
\hline$W[C / 38]$ & Slavonski Brod (Hr) & 2010 & Biharugra Fishpond & 2014 & $A$ & $5 y$ & 356 \\
\hline W/W [C/2X] & Slavonski Brod (Hr) & 2011 & Lake Csaj & 2016 & A & $6 y$ & 236 \\
\hline$B / B[5 L]$ & Kapetanski Rit (RS) & 2005 & Hortobágy Fishpond & 2011 & A & $7 y$ & 198 \\
\hline \multirow{3}{*}{$\mathrm{B} / \mathrm{B}[1 \mathrm{G}]$} & \multirow{3}{*}{ Becej (RS) } & \multirow{3}{*}{2005} & \multirow{3}{*}{ Szeged Fishpond } & 2009 & A & $5 y$ & 89 \\
\hline & & & & 2010 & A & $6 y$ & 89 \\
\hline & & & & 2013 & A & $9 y$ & 89 \\
\hline W/W [7P] & Becej (RS) & 2004 & Bakonszeg & 2015 & A & $12 y$ & 214 \\
\hline W/W [B0] & Becej (RS) & 2005 & Derzsi Fishpond & 2009 & A & $5 y$ & 239 \\
\hline $\mathrm{B} / \mathrm{B}[3 \mathrm{C}]$ & Jazovo (RS) & 2005 & Szeged Fishpond & 2012 & $A$ & $8 y$ & 52 \\
\hline \multirow{2}{*}{$\mathrm{B} / \mathrm{W}[\mathrm{PG}]$} & \multirow{2}{*}{ Becej (RS) } & \multirow{2}{*}{2007} & Lake Csaj & 2011 & A & $5 y$ & 117 \\
\hline & & & Lake Kolon? & 2012 & $A^{*}$ & $6 y$ & $147 ?$ \\
\hline $\mathrm{B} / \mathrm{W}$ [ZE] & Becej (RS) & 2007 & Lake Csaj & 2016 & A & $10 y$ & 117 \\
\hline $\mathrm{B} / \mathrm{B}[4 \mathrm{H}]$ & Jazovo (RS) & 2007 & Hortobágy Fishpond & 2013 & A & $7 y$ & 205 \\
\hline W [E/N8] & Becej (RS) & 2009 & Lake Csaj & 2016 & A & $8 y$ & 117 \\
\hline $\mathrm{W}[\mathrm{E} / 9 \mathrm{~V}]$ & Becej (RS) & 2011 & Gácsháti Fishpond & 2015 & A & $5 y$ & 169 \\
\hline$W[E / 3 A]$ & Coka (RS) & 2011 & Szeged Fishpond or Lake Csaj & 2015 & $B^{*}$ & $5 y$ & $45-74$ \\
\hline$W[E / 2 E]$ & Coka (RS) & 2011 & Lake Csaj & 2016 & A & $6 y$ & 74 \\
\hline$W[E / 3 T]$ & Coka (RS) & 2011 & Szeged Fishpond & 2015 & A & $5 y$ & 45 \\
\hline$W[X 7]$ & Nibe (DK) & 2004 & Balaton area & 2013 & A & $10 y$ & 1255 \\
\hline $\mathrm{R} / \mathrm{B}[\mathrm{XH}]$ & Danube Delta (Ro) & 2003 & Derzsi Fishpond & 2007 & A & $5 y$ & 687 \\
\hline
\end{tabular}

$129.6 \pm 63.6 \mathrm{~km}(\mathrm{mean} \pm \mathrm{SD})$ from Serbia, $223.8 \pm 83.1 \mathrm{~km}$ from Croatia, $273.3 \pm 61.3 \mathrm{~km}$ from the Czech Republic and $500.0 \pm 19.0 \mathrm{~km}$ from Italy. Only 5.5\% (43 out of 781) of the juveniles from Croatia and 4.7\% (32 out of 685) of the juveniles from Serbia were long-distance dispersers in Hungary. All individuals visiting Hungary from the Czech Republic and Italy were long-distance dispersers.

\section{Immatures (2cy and 3cy)}

Only ten 2cy individuals were observed in Hungary, eight of which were of Carpathian Basin origin, while two birds arrived from Italy. A 2cy old individual with Austrian origin was recovered in Hungary, but the circumstances are not known in detail.

Thirty-six individuals were observed in Hungary at their age of 3cy. Thirty-one individuals were marked in the Carpathian Basin, while four were from Italy and one from The Netherlands.

\section{Subadults (4cy)}

Fourty-eight Spoonbills were observed in Hungary at their age of 4cy, one was from the Czech Republic and another one from The Netherlands, while four arrived from Italy, eleven from Croatia and 31 from Serbia. An individual from Italy was observed in Hungary on 
6 April 2016 and the same individual was seen in Italy from 1 June 2016. Two Spoonbills at the age of 4cy were observed in heron colonies during breeding season $142 \mathrm{~km}$ (hatched in Serbia) and $685 \mathrm{~km}$ (hatched in Italy) far from their natal colonies.

\section{Adults (4+)}

Eighty adult (4+) Spoonbills were

Table 6. The origin of Spoonbills from abroad, and their observed in Hungary. Six were from the Czech Republic, three from Austria, one from Romania, one from Denmark and one from The Netherlands, while four were ringed in Italy, 15 in Croatia and 48 in Serbia. Furthermore, an adult bird was captured during breeding in Italy and equipped with a GPS-logger was also detected in Hungary, but the natal area of that individual remained unknown.

I found that 20 Spoonbills were possible breeders in Hungary and breeding probability in Hungary and the Austrian part of Lake Neusiedler. A: possible breeding; B: probable breeding; C: confirmed breeding

6. táblázat A Magyarországon megfigyelt kanalasgémek származása és fészkelési valószínűsége a magyar és a Fertő osztrák oldalán lévő telepeken. A: lehetséges fészkelő; B: valószínú fészkelő; C: biztos fészkelő

\begin{tabular}{|l|r|r|r|r|}
\hline \multicolumn{1}{|c|}{ Origin } & A & B & C & Total \\
\hline Denmark & 1 & & & 1 \\
\hline The Netherlands & & 1 & & 1 \\
\hline Czech Republic & 2 & 1 & & 3 \\
\hline Croatia & 4 & 5 & 1 & 10 \\
\hline Serbia & 12 & 7 & 1 & 20 \\
\hline Romania (Danube Delta) & 1 & & & 1 \\
\hline
\end{tabular}
the Austrian part of Lake Neusiedler (Table 6, Figure 11), while 14 individuals were probable breeders (Table 6, Figure 12). I found that only two foreign Spoonbills (one with Serbian and one with Croatian origin) were confirmed breeders in Hungary (Table 6, Figure 13). Thus, a total of 37 individuals of foreign origin had any probability of breeding in Hungary. In the case of nine individuals $(24.3 \%, \mathrm{n}=37)$, dispersal between the natal area and the breeding site during adulthood was less than a hundred kilometres, while in the case of 28 Spoonbills $(75.7 \%, \mathrm{n}=37)$ this dispersal was probably long-distance dispersal $(>100 \mathrm{~km})$ (Figure 14). Six individuals $(16.2 \%$, $\mathrm{n}=37)$ were hatched outside of the Carpathian Basin, and three $(8.1 \%, \mathrm{n}=37)$ of which belong to populations that do not have their main migration route along the Central Mediterranean or Adriatic Flyway.

Interestingly, an adult (5cy) individual from Italy was observed at Pusztaszer, Hungary on 28 March 2007, and later the same individual was seen in the vicinity of colonies in Italy on 17 June 2007.

\section{Discussion}

Hungarian wetlands play a key role for Spoonbills in Central Europe. Resighted birds originated from eight countries. Most of the birds came from the Czech Republic and from the Carpathian Basin (Serbia, Croatia and Austria), but a few Spoonbills regularly visited Hungary from Italy, while individuals from the Wadden Sea area, and the Danube Delta 


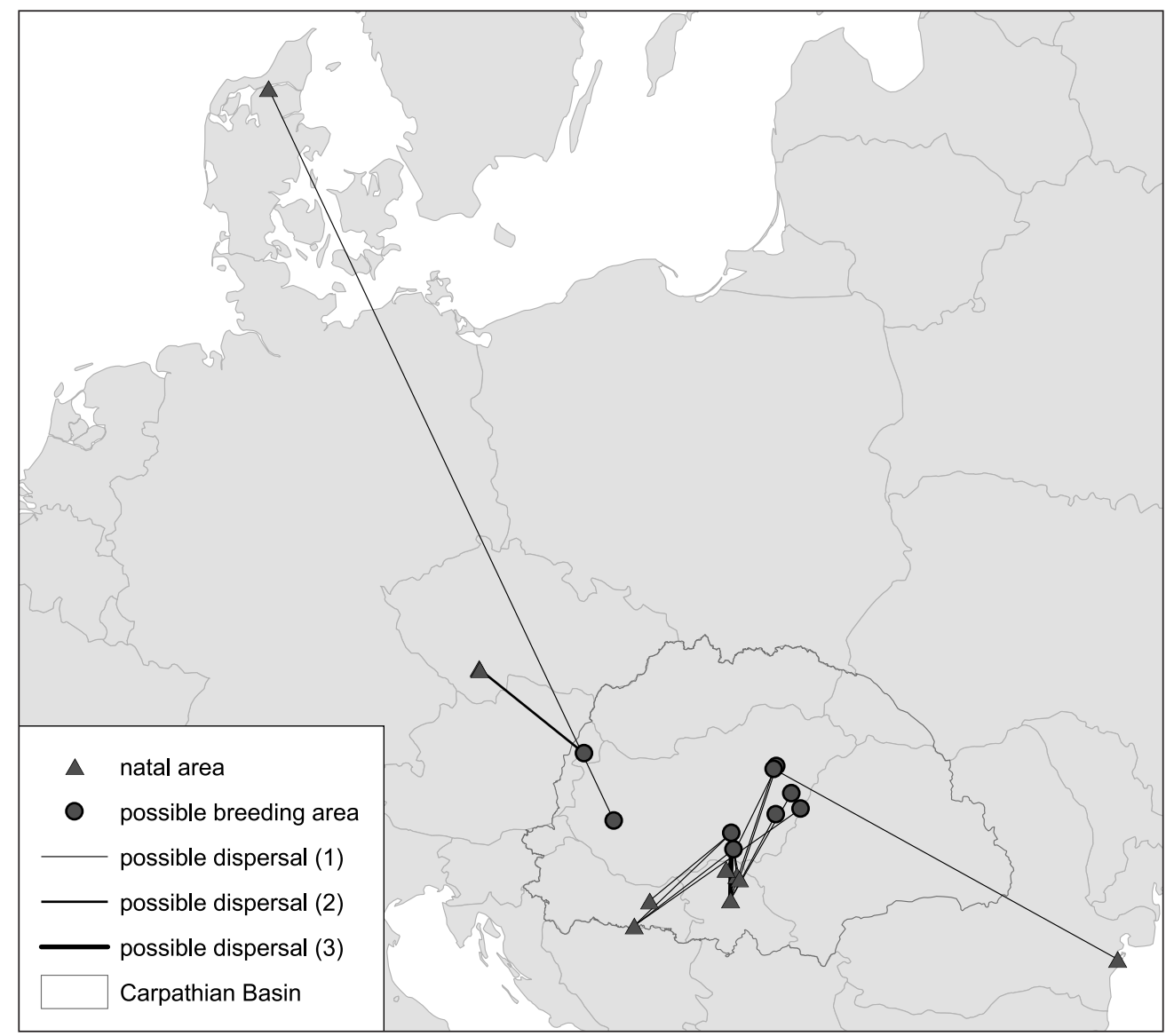

Figure 11. Possible dispersal between natal area and breeding sites during adulthood. Number in parentheses indicates the number of individuals

11. ábra Lehetséges diszperzió a kikelési hely és a fészkelőhely között. A zárójelben levő számok az egyedszámot mutatják

were found occasionally. Furthermore, it is known that a colour-ringed Spoonbill hatched in Greece was observed in Croatia (Kralj 2013). Thus, the population in the Carpathian Basin is connected with several other populations breeding in Europe outside of the Carpathian Basin, however data show only marginal connections between birds of the Carpathian Basin and individuals of Greece, the Danube Delta and the Wadden Sea Area. We have no data from Iberian or East European birds in the Carpathian Basin.

Previous studies supposed that European Spoonbills form two distinct populations: one in Central and Southeast Europe, and another one along the East Atlantic coast of Europe (Brouwer 1964, Triplet et al. 2008). Brouwer (1964) did not find evidence for gene flow between those populations and the two populations also had different wintering areas that time. However, an overlap of the wintering areas of these two populations has been found recently (Smart et al. 2007, Pigniczki \& Karcza 2013). My results indicate that birds marked in the Wadden Sea area may join flocks of birds breeding in the Carpathian Basin. It is clear 


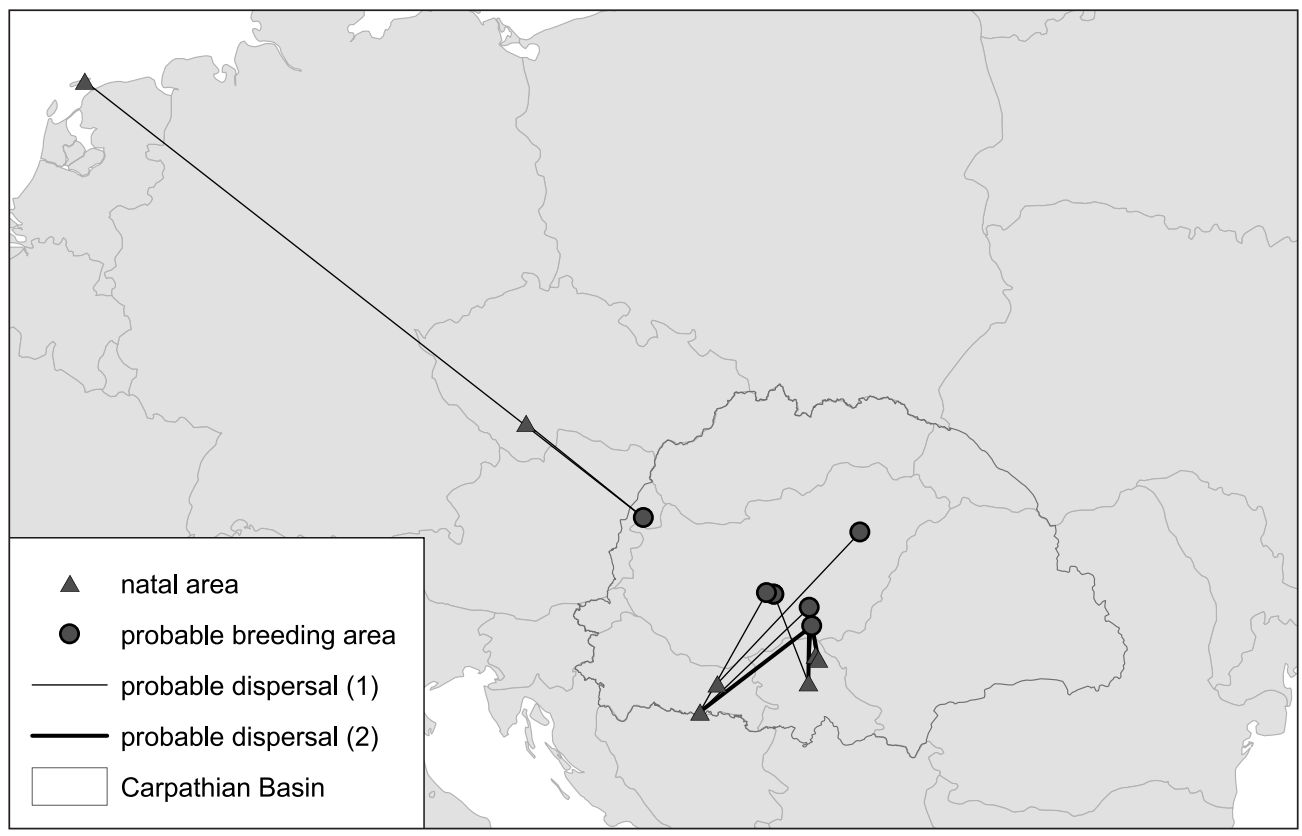

Figure 12. Probable dispersal between natal area and probable breeding sites. Number in parentheses indicates the number of individuals

12. ábra Feltételezett diszperzió a kikelési hely és a feltételezett fészkelöhely között. A zárójelbe írt szám a madarak számát jelzi

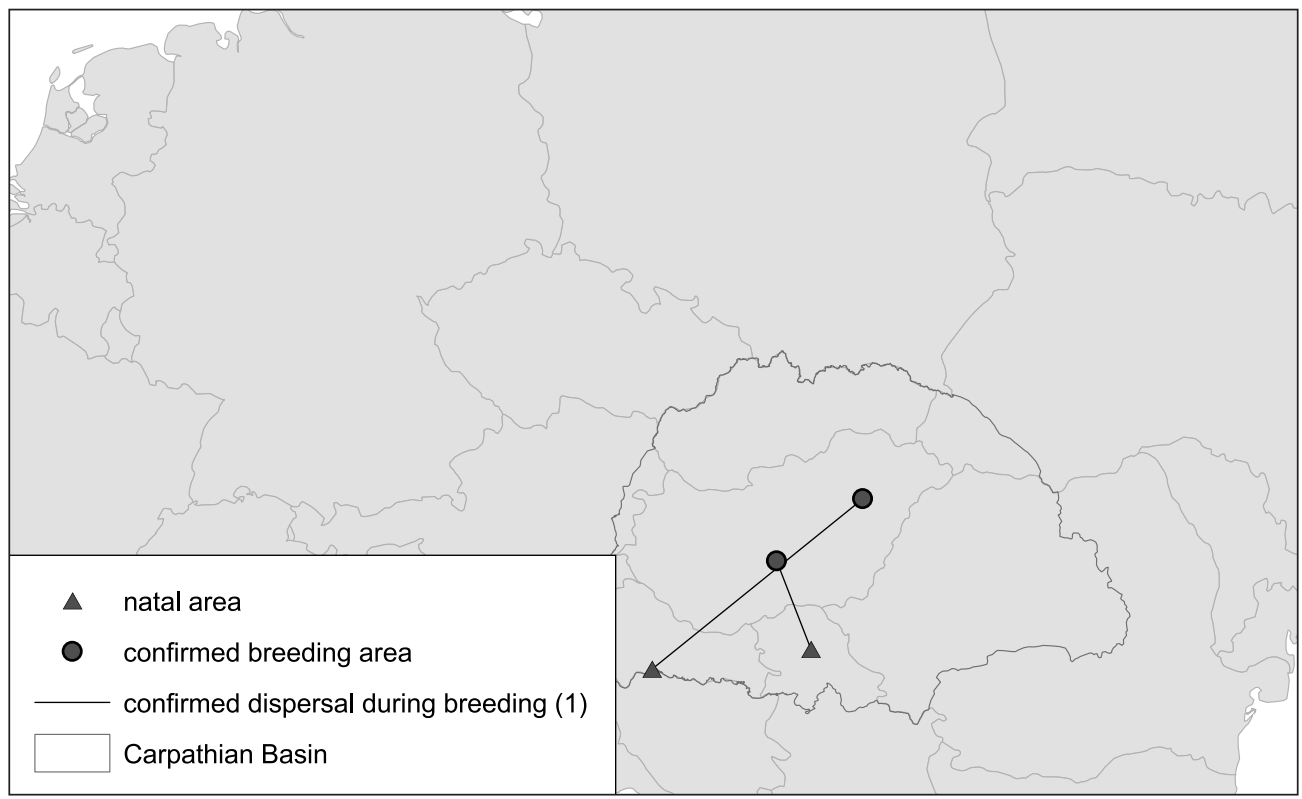

Figure 13. Confirmed dispersal between natal area and possible breeding sites. Number in parentheses indicates the number of individuals

13. ábra Diszperzió a kikelési hely és a fészkelőhely között. A zárójelbe írt szám a madarak számát jelzi 


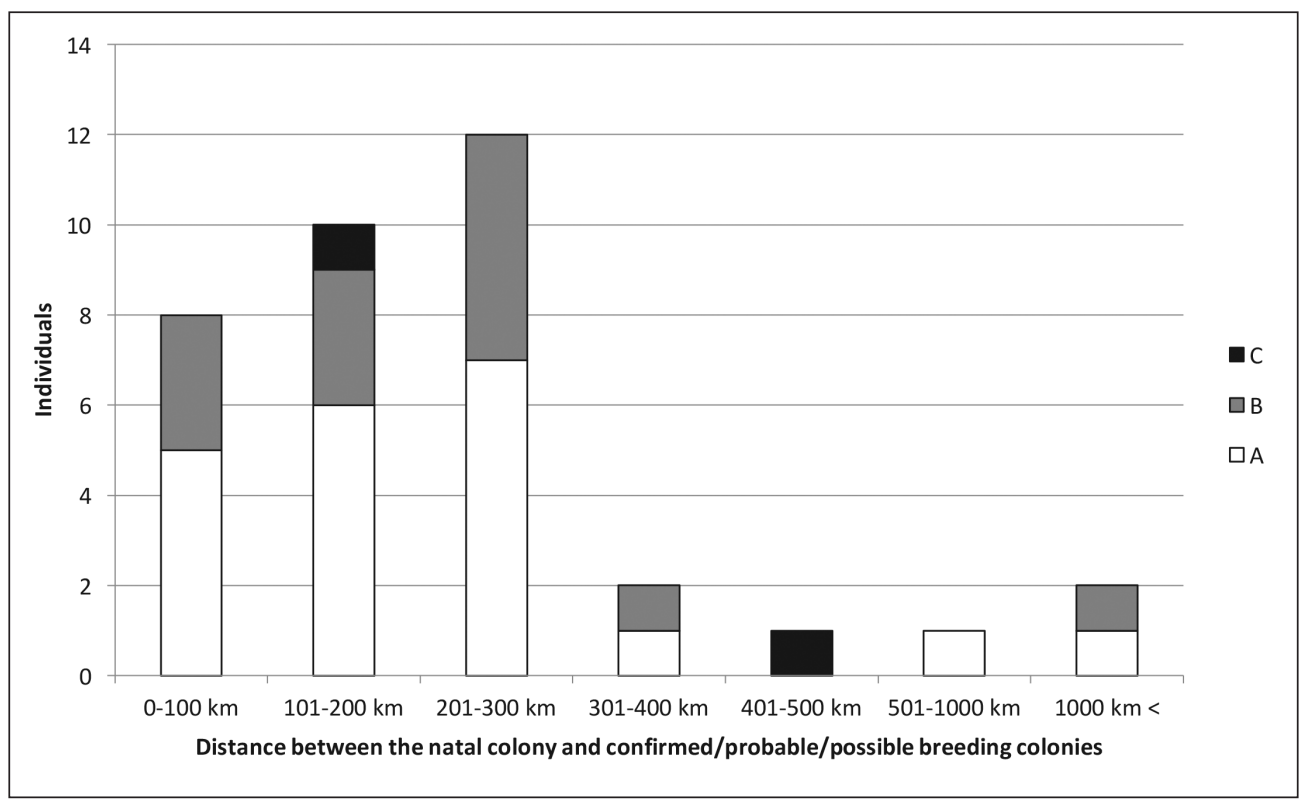

Figure 14. Distribution of distances between the natal colony and possible (A) / probable (B) / confirmed (C) breeding colonies in Hungary and Lake Neusiedler in case of Spoonbills of foreign origin

14. ábra A kikelési hely és a lehetséges (A) / feltételezett (B) / biztos (C) fészkelőhelyek közötti távolságok eloszlása Magyarországon és a Fertőn a külföldön jelölt kanalasgémek esetében

from my results that adults from the Central European and the East Atlantic populations are not totally separated. Adults from the two populations may meet in the Carpathian Basin during the breeding season, implying that gene flow is probable between the two populations. Furthermore, adult Spoonbills from the Czech Basin and the Danube Delta were also observed in the Carpathian Basin during the breeding season. I found no record of adults with Italian origin during the breeding season in the Carpathian Basin, although such birds were observed in Hungary before and after the breeding season. However, it is still possible that birds from Italy take part in gene flow with the Carpathian Basin population. ${ }^{1}$ For example, an adult Spoonbill that bred in Italy visited the Carpathian Basin in two consecutive years to oversummer there without any known breeding activity (Pigniczki et al. 2016). The natal area of that individual is unknown because it was marked as an adult.

Spoonbills of Hungarian origin mainly use the Central Mediterranean Flyway and the Adriatic Flyway, however, a few individuals migrated along East Mediterranean and East Atlantic Flyway (Pigniczki et al. 2016), and similar results are known in case of other countries of the Carpathian Basin (Müller 1984, Kralj et al. 2012, Pigniczki et al. 2016). It was found that Spoonbills colour-ringed in Hungary dispersed and bred within the Carpathian Basin (Pigniczki \& Végvári 2015). Long-distance dispersal of potential breeders of Hungarian origin was supposed in one case outside of the border of the Carpathian Basin based

\footnotetext{
${ }^{1}$ Three adult Spoonbills of Italian origin were observed after the study period in Hungary, during the breeding season of 2017. These birds are treated as possible breeders, so gene flow from Italian colonies is probable.
} 
on data of metal ringing. A Spoonbill marked at Kis-Balaton, Hungary was found dead in May near a colony in the lower Danube in Romania at its 7cy (Pigniczki 2010). Furthermore, an individual marked in Croatia was seen in its 7cy in a colony in the Czech Republic (Cepak 2008).

My results provide new evidence on patterns in dispersal within the Carpathian Basin, because high numbers of Austrian, Serbian and Croatian adults (4+) were reported in Hungary and Lake Neusiedler during the breeding season. Dispersal of adults between their natal colonies and breeding colonies during the breeding season was mostly long-distance $(100 \mathrm{~km}<)$ dispersal (almost $80 \%$ of dispersal events). For adult Spoonbills from Austria, long-distance dispersal was supposed for all observations during the breeding season in Hungary (Pigniczki 2010). It is important to note that these results show only the dispersal rate in the relation of eight countries and Hungary during the breeding period, which does not allow generalisations about the dispersal of the Spoonbills in the Carpathian Basin between natal sites and subsequent breeding sites. The long-distance dispersal rate of the Spoonbills in the Carpathian Basin during breeding was estimated at around $20 \%$ based on Hungarian ringing results (Pigniczki \& Végvári 2015). Most of the Spoonbills observed in Hungary were 1cy old, and very few were 2cy old. Spoonbills generally suffer large mortality during their first year of life (Pigniczki 2010, Lok 2013b) and only a few immature Spoonbills return to their natal area, because most of them stay in the wintering ground or in proper wetlands between the wintering area and the natal area (Pigniczki 2015, Pigniczki \& Végvári 2015).

Juveniles reached Hungary during their post-fledging dispersal from Italy from middle of June and from Serbia and Croatia from early July. Juveniles that reached Hungary from the Czech Republic are supposed to be migrants on their stop-over or staging area. Spoonbills in immature or sub-adult stages also visited Hungary. These birds were found to spend time not only in the foraging areas, but also in Spoonbill colonies in Hungary. Taken together, these movements may help juveniles, immatures and sub-adults to decide where to breed in the future (Pigniczki \& Végvári 2015). Such behaviour was suspected also in immature Gannets (Morus bassanus) (Votier et al. 2011) and Glossy Ibises (Plegadis falcinellus) (Santoro et al. 2013).

Movement of an adult (5cy) individual before the breeding season showed that spoonbills might also make explorative movements to collect information on the wetlands as potential breeding sites, which may thus influence the decision on where to breed. An alternative explanation is if that individual searched for areas suitable for feeding as it had arrived from its spring migration shortly before the observations. Because it was not known whether this individual bred anywhere, further data are needed to decipher its behaviour.

Spoonbills from the Czech Republic, Italy and the Carpathian Basin generally migrate along the Adriatic Flyway and the Central Mediterranean Flyway (Triplet et al. 2008, Kralj et al. 2012, Pigniczki et al. 2016), and the wetlands of Hungary can be part of both flyways. Spoonbills from the Wadden Sea area mainly follow the East Atlantic Flyway, and move to the Atlantic coast of France, Iberia or sub-Saharan Africa (Lok et al. 2011, 2013a, 2013b), however, a few individuals were also observed in Tunisia (Smart et al. 2007). A few Spoonbills of East Atlantic origin also reached continental Central Europe. Interestingly, some of them were able to find their way back to West Europe, while others seemed to shift their 
breeding areas and their migration routes as well, and visit Central Europe regularly during the breeding season, although their breeding could not yet be confirmed.

Spoonbills hatched in the Danube Delta mainly use a different flyway to their wintering areas, and only a few individuals touch the Adriatic or Central Mediterranean Flyway, and spend winter in Tunisia (Kiss et al. 2007, Pigniczki et al. 2016). One of the Spoonbills (5cy) from the Danube Delta, which was previously observed in Tunisia probably joined the migrating individuals of Carpathian Basin origin and reached Hungary while they were moving together. It is possible that inexperienced individuals are led by experienced birds during migration, as it is supposed in White Storks (Ciconia ciconia) (Chernetsov et al. 2004). White Storks and Spoonbills are also social birds during their migration, and social interactions may play important role in the decisions of inexperienced individuals, probably also in those of inexperienced young adults.

Two possible examples for overshoots during spring migration were observed in the case of Spoonbills of Italian origin in Hungary. Both individuals were seen in Hungary during late March and early April, and later in Italy by June. Both individuals (4cy and 5cy) were likely to be inexperienced in breeding. They probably joined migrating flocks of breeders of the Carpathian Basin, and finally reached Hungary migrating together with that flock. These two individuals eventually found their way back to their natal area in Italy, thus, probably providing examples of natal site fidelity.

It is important to note the high proportion of Spoonbills from the Czech Republic that use the Lake Neusiedler during the autumn migration as a stop-over or staging area. This result indicates that habitat reconstruction and habitat management activities on wetlands around Lake Neusiedler (Pellinger 2001) are very important for Spoonbills as a specialist waterbird of shallow wetlands.

The observation of the hybrid Eurasian Spoonbill $\times$ African Spoonbill in Hungary means a potential threat to the population of Eurasian Spoonbill in the Carpathian Basin. African Spoonbills found in Europe are supposed to be escaped birds from bird collectors (Svensson et al. 2010). An African Spoonbill has bred in the colony of Eurasian Spoonbill at the Po Delta in Italy together with Sacred Ibis (Threskiornis aethiopicus), and not only the hybrid of African Spoonbill $\times$ Eurasian Spoonbill were observed there, but also the hybrid of African Spoonbill $\times$ Sacred Ibis (Platalea alba $\times$ Threskiornis aethiopicus) (Volponi et al. 2008). These hybrids are the results of human impacts (introduction or escapes from captivity). Both types of hybrids, if they are fertiles, could mean problems for the genetic variability of Eurasian Spoonbills. Human impacts on hybridisation cause problems in nature conservation by compromising and deteriorating the genetic composition of native, wild animals (Oliveira et al. 2008). On the other hand, other hybridizations e.g. between Eurasian Spoonbill and Black-faced Spoonbill (Platalea minor) under natural way can be evolutionarily important, because novel combination of genes and alleles can create favourable genetic conditions (Kwon et al. 2017).

In summary, I showed that the dispersal plays a very important role in the Spoonbill population in the Carpathian Basin. Dispersal between natal area and breeding sites during adulthood is probably widespread among the colonies of the Carpathian Basin, which probably has a positive influence on the genetic variability of this population. Furthermore, my study 
shows that immigration of Spoonbills from the Czech Republic, the Wadden Sea area and the Danube Delta is possible, and they might breed in the Carpathian Basin, implying the existence of gene flow at continental scale. Furthermore, the wetlands of the western part of the Carpathian Basin play an important role for the Spoonbills from the Czech Republic during migration.

\section{Acknowledgement}

I thank Hichem Azafzaf, Mohamed-Ali Dakhli, Petra de Goeij, Zsolt Karcza, János Botond Kiss, Jelena Kralj, Tamar Lok, Katalin Odett Lukács, Pierfrancesco Micheloni, Tibor Mikuska, Otto Overdijk, Jaroslav Simek, Michael Smart, Adriano Talamelli, Stefano Volponi and Antun Žuljević for their kind help during data management. I also thank all ring readers for reporting their observations. Spoonbill colour-ringing was supported in Central Europe by Werkgroep Lepelaar (Dutch Spoonbill Working Group). The Hungarian Bird Ringing Centre was financially supported by Ministry of Agriculture. I thank Szabolcs Lengyel, Tibor Csörgő and Zsolt Végvári for valuable comments on an earlier version of the manuscript.

\section{References}

Brouwer, G. A. 1964. Some data on the status of the Spoonbill, Platalea leucorodia L., in Europe, especially in the Netherlands. - Zoologische Mededelingen 39(48): 481-521.

De le Court, C. \& Aguilera, E. 1997. Dispersal and migration in Eurasian Spoonbills Platalea leucorodia. - Ardea 85: 193-202.

Cepák, J. P. 2008. Kolpík bílý [Spoonbill]. - In: Cepák, J., Klvaňa, P., Škopek, J., Schröpfer, L., Jelínek, M,. Hořák, D., Formánek, J. \& Zárybnický, J. (eds.) Atlas migrace ptáku Ceské a Slovenské Republiky [Czech and Slovak Bird Migration Atlas]. - Aventinum, Praha, pp. 268-269. (in Czech with English Summary)

Chernetsov, N., Berthold, P. \& Querner, U. 2004. Migratory orientation of first-year White Storks (Ciconia ciconia): inherited information and social interactions. - The Journal of Experimental Biology 207: 937-943. DOI: $10.1242 /$ jeb.00853

Hammer, Ø., Harper, D. A. T. \& Ryan, P. D. 2001. PAST: Paleontological Statistics Software Package for education and data analysis. Palaeontologia Electronica 4(1): 1-9.

Kiss, J. B., Sándor, D. A., Marinov, E. M. \& Overdijk, O. 2007. New data regarding the migration of Spoonbills (Platalea leucorodia) breeding in the Danube Delta, based on color ring resightings. - Scientific Annals of Danube Delta Institute 13: 45-50.

Kralj, J. 2013. Zlicarka Platalea leucorodia [Eurasian Spoonbill]. - In: Kralj, J., Barisic, S., Tutis, V. \& Cikovic, D. (eds.) Atlas selidbe ptica Hrvatske [Croatian Bird Migration Atlas]. - Hrvatska Akademija Znanosti i Umjetnosti, Zagreb, pp. 46-48. (in Croatian with English Summary)

Kralj, J., Žuljević., A., Mikuska, T. \& Overdijk, O. 2012. Movements of immature Eurasian Spoonbills Platalea leucorodia from the breeding grounds of the Eastern metapopulation in the Pannonian Basin. - Waterbirds 35(2): 239-247. DOI: 10.1675/063.035.0206

Kralj, J., Mikuska, T., Šetina, M. \& Overdijk, O. 2013. Dispersal and migration of Eurasian Spoonbills breeding in Croatia. - In: Navedo, J. G. (ed.) Proceedings of the Eurosite VII. Spoonbill Workshop, Cantabria, Spain, pp. 48-52.

Kwon, I. K., Lee, K. S., Lee, J. Y., Park, J. H. \& Yoo, J. C. 2017. Hybridization between the Black-faced Spoonbill (Platalea minor) and Eurasian Spoonbill (Platalea leucorodia) in South Korea. - Waterbirds 40: 77-81. DOI: $10.1675 / 063.040 .0112$

Lok, T., Overdijk, O., Tinbergen, J. M. \& Piersma, T. 2011. The paradox of Spoonbill migration: most birds travel to where survival rates are lowest. - Animal Behaviour 82(4): 837-844. DOI: 10.1016/j.anbehav.2011.07.019 
Lok, T., Overdijk, O. \& Piersma, T. 2013a Migration tendency delays distributional response to differential survival prospects along a flyway. - The American Naturalist 181(4): 520-531. DOI: 10.1086/669679

Lok, T., Overdijk, O., Tinbergen, J. M. \& Piersma, T. 2013b Seasonal variation in density dependence in age-specific survival of a long-distance migrant. - Ecology 94(10): 2358-2369. DOI: 10.1890/12-1914.1

Müller, C. Y. 1984. Bestandsentwicklung und Zugverhalten der Löffler (Platalea leucorodia L.) im österreichisch-ungarischen Raum. - Egretta 27: 45-67. (in German)

Navedo, J. G., Orizaola, G., Masero, J. A., Overdijk, O. \& Sánchez-Guzmán, J. M. 2010. Long-distance travellers stopover for longer: a case study with Spoonbills staying in North Iberia. - Journal of Ornithology 151(4): 915-921. DOI: 10.1007/s10336-010-0530-z

Oliveira, R., Godinho, R., Randi, E. \& Alves, P. C. 2008. Hybridization versus conservation: are domestic cats threatening the genetic integrity of Wildcats (Felis silvestris silvestris) in Iberian Peninsula? - Philosophical Transactions of the Royal Society of London B: Biological Sciences 363(1505): 2953-2961. DOI: 10.1098/ rstb.2008.0052

Overdijk, O. 2008. Colour ringing efforts in some countries in the period 2002-2007. - Spoonbill Network Newsletter 5: 1 .

Overdijk, O. \& Navedo, J. G. 2012. A massive Spoonbill stopover episode: identifying emergency sites for the conservation of migratory waterbird populations. - Aquatic Conservation: Marine and Freshwater Ecosystems 22(5): 695-703. DOI: $10.1002 / a q c .2275$

Pellinger, A. 2001. Mekszikópusztai elárasztások [Habitat reconstruction area at Mekszikópuszta]. - Túzok 6: 132-141. (in Hungarian with English Summary)

Pigniczki, Cs. 2009. Kanalasgém (Platalea leucorodia) [Spoonbill (Platalea leucorodia)]. - In: Csörgö, T., Karcza, Zs., Halmos, G., Magyar, G., Gyurácz, J., Szép, T., Bankovics, A., Schmidt, A. \& Schmidt, E. 2009. Magyar Madárvonulási Atlasz [Hungarian Bird Migration Atlas]. - Kossuth Kiadó, Budapest, pp. 195-198. (in Hungarian with English Summary)

Pigniczki, Cs. 2010. Magyarországi kanalasgémek (Platalea leucorodia) kóborlása és vonulása fémgyürüs megkerülések alapján [Dispersion and migration of Hungarian Spoonbills (Platalea leucorodia) based on recoveries of metal-ringed individuals]. - Aquila 116-117: 17-32. (in Hungarian with English Summary)

Pigniczki, Cs. 2015. A magyar gyürüs kanalasgémek (Platalea leucorodia) diszperziója és vonulása [Dispersal and migration of Spoonbills (Platalea leucorodia) ringed in Hungary]. - PhD Thesis, Debreceni Egyetem, Debrecen (in Hungarian with English Summary)

Pigniczki, Cs. 2016. Observation of unusually large flock of roosting Spoonbills (Platalea leucorodia) on Büdösszék of Kiskunság. - Aquila 122-123: 131-132.

Pigniczki, Cs. 2017. Unique prey handling of Eurasian Spoonbill (Platalea leucorodia). - Waterbirds 40: 74-76. DOI: $10.1675 / 063.040 .0111$

Pigniczki, Cs. \& Karcza, Zs. 2006. First results of Spoonbill colour-ringing project in Hungary (2003-2005). Spoonbill Network Newsletter 4: 8-9.

Pigniczki, Cs. \& Karcza, Zs. 2013. Movements of Eurasian Spoonbill based on metal- and colour-ringing recoveries between 1908 and 2012 in Hungary. - In: Navedo, J. G. (ed.) Proceedings of the Eurosite VII. Spoonbill Workshop, Cantabria, Spain, pp. 59-65.

Pigniczki, Cs. \& Végvári, Zs. 2015. Dispersal of the Central European population of the Eurasian Spoonbill Platalea leucorodia. - Ardeola 62(2): 219-236. DOI: 10.13157/arla.62.2.2015.219

Pigniczki, Cs., Kralj, J., Volponi, S., Žuljević, A., Dakhli, M-A., Mikuska, T., Azafzaf, H. \& Végvári, Zs. 2016. Migration routes and stopover sites of the Eurasian Spoonbill (Platalea leucorodia) between the Carpathian Basin and wintering areas. - Ornis Hungarica 24(1): 128-149. DOI: 10.1515/orhu-2016-0008

Pigniczki, Cs., Mikuska, T., Nagy, Sz., Bino, T., Kotrosan, D., Sarac, M., Sackl, P., Saveljic, D., Feltrup-Azafzaf, C., Smart, M., Emiliani, D., Durst, R. \& Navedo, J. G. 2017. Improving connectivity for the conservation of the Central European population of the Eurasian Spoonbill: conclusions from the $2^{\text {nd }}$ Adriatic Flyway Conference. - In: Sackl, P. \& Ferger, S. (eds.) Adriatic Flyway - Bird Conservation on the Balkans. - Euronatur, Radolfzell, pp. 161-167.

R Development Core Team 2016. R: A language and environment for statistical computing. - R Foundation for Statistical Computing, Vienna, Austria. https://www.R-project.org/

Santoro, S., Green, A. J. \& Figuerola, J. 2013. Environmental instability as a motor for dispersal: a case study from a growing population of Glossy Ibis. - PLoS ONE 8: e8293. DOI: 10.1371/journal.pone.0082983

Smart, M., Azafzaf, H. \& Dlensi, H. 2007. The 'Eurasian' Spoonbill (Platalea leucorodia) in Africa. - Ostrich 78(2): 495-500. DOI: 10.2989/OSTRICH.2007.78.2.60.174 
Sullender, B. K., Barzen, J. \& Silbernagel, J. 2016. Foraging success and habitat selection of the Eurasian Spoonbill (Platalea leucorodia) at Poyang Lake, China. - Waterbirds 39(4): 356-364. DOI: 10.1675/063.039.0405 Svensson, L., Mullarney, K. \& Zetterström, D. 2010. Collins Bird Guide. - Printer, Trento, Italy

Triplet, P., Overdijk, O., Smart, M., Nagy, Sz., Schneider-Jacoby, M., Sühendan Karauz, E., Pigniczki, Cs., Baha El Din, S., Kralj, J., Sándor, A. \& Navedo, J. G. 2008. International Single Species Action Plan for the Conservation of the Eurasian Spoonbill. - AEWA Technical Series 35.

Vavrek, M. J. 2011. Fossil: Paleoecological and paleogeographic analysis tools. - Palaeontologia Electronica 14: 16.

Volponi, S., Emiliani, D. \& Sighele, M. 2008. Nidificazioni ibride di Spatola Africana Platalea alba a Valle Mandriole (RA) [Mixed breedings of African Spoonbill Platalea alba at Valle Mandriole (RA, Italy)]. - Quaderni di Birdwatching 10. http://www.ebnitalia.it/QB/QB020/index.htm (accessed on 13 January 2017). (in Italian with English Summary)

Votier, S. C., Grecian, W. J., Patrick, S. \& Newton, J. 2011. Inter-colony movements, at-sea behaviour and foraging in an immature seabird: results from GPS-PTT tracking, radio-tracking and stable isotope analysis. Marine Biology 41: 621-626. DOI: 10.1007/s00227-010-1563-9

http://www.crb-photoguide.com (accessed on 13 January 2017)

http://www.cr-birding.org (accessed on 13 January 2017)

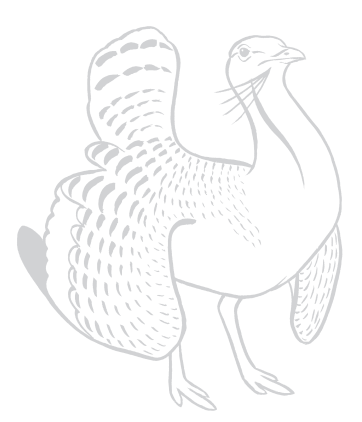

